\title{
Physiological response to temperature, light, and nitrates in the giant kelp Macrocystis pyrifera from Tasmania, Australia
}

\author{
Christopher J. T. Mabin ${ }^{1, *}$, Craig R. Johnson ${ }^{2}$, Jeffrey T. Wright ${ }^{2}$ \\ ${ }^{1}$ Institute for Marine and Antarctic Studies, University of Tasmania, Launceston, TAS 7250, Australia \\ ${ }^{2}$ Institute for Marine and Antarctic Studies, University of Tasmania, Hobart, TAS 7001, Australia
}

\begin{abstract}
Climate change is characterised by multiple abiotic forcings acting simultaneously on biotic systems. In marine systems, temperature appears to drive much of the observed change in biotic communities subject to climate change, but this may reflect the focus of most studies only on temperature without consideration of other environmental variables affected by climate change. The giant kelp Macrocystis pyrifera was once abundant in eastern Tasmania, forming extensive habitats of ecological and economic importance, but recent extensive population decline has occurred. Southerly incursion of warm oligotrophic East Australian Current (EAC) water has increased in frequency and intensity into this region, which has warmed $\sim 4$ times the global average, and the warming trend is predicted to continue. This study investigated the single and combined effects of temperature, light, and nitrate availability on the physiology of juvenile $M$. pyrifera sporophytes in a laboratory experiment. Determination of relative growth rate, photosystem II characteristics, pigments, elemental chemistry, and nucleic acid characteristics over $28 \mathrm{~d}$ showed that all experimental factors affected sporeling physiology. Temperature and light drove much of the observed variation related to performance characteristics, and rapid deterioration of kelp tissue was a consequence of temperature stress (high temperature), photoinhibition (high light), and low light, accompanied by impaired photosynthetic efficiency and increased RNA concentration, presumably associated with production of photoprotective proteins. Surprisingly, higher relative growth rates were observed in low-nitrate treatments. These findings suggest that negative effects of temperature on $M$. pyrifera populations will be mediated by local variation in light and nutrient conditions.
\end{abstract}

${ }^{*}$ Corresponding author: chris.mabin@utas.edu.au

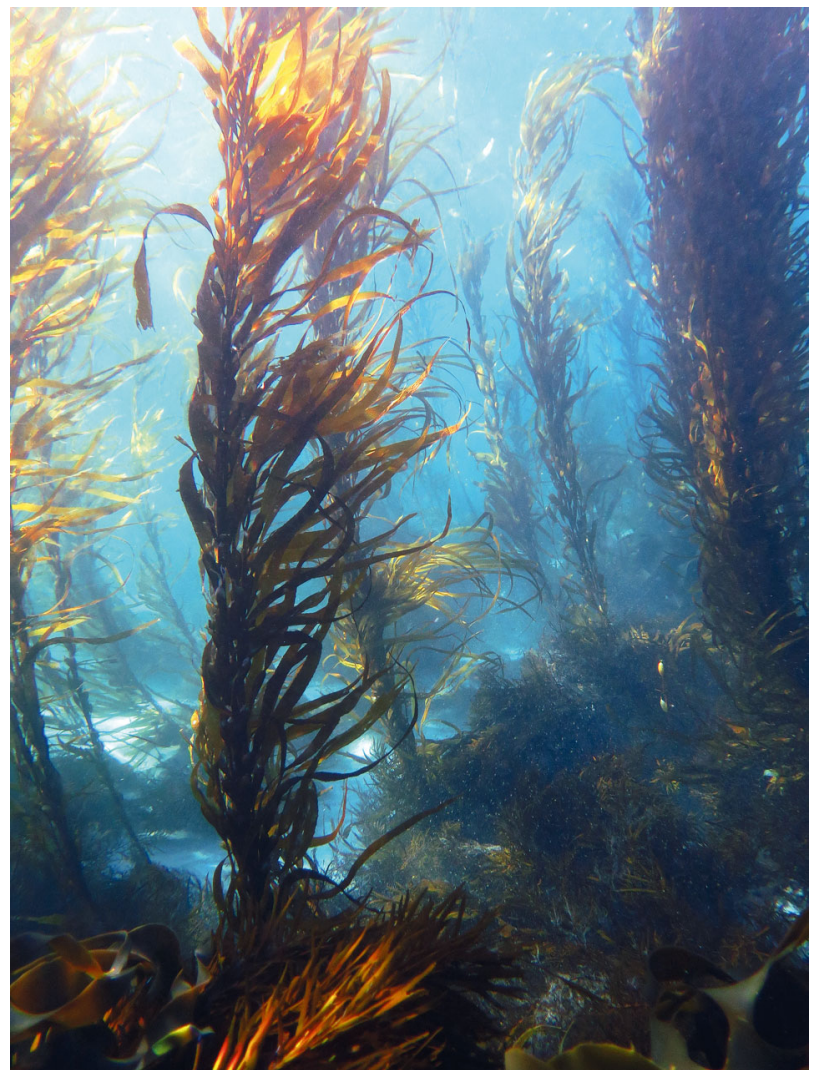

Vanishing underwater forest: One of the last remaining patches of giant kelp on the east coast of Tasmania.

Photo: Cayne Layton

KEY WORDS: Kelp $\cdot$ Climate change $\cdot$ Macrocystis pyrifera $\cdot$ Relative growth $\cdot$ Photosynthesis $\cdot$ Physiology $\cdot$ Morphology

(C) The authors 2019. Open Access under Creative Commons by Attribution Licence. Use, distribution and reproduction are unrestricted. Authors and original publication must be credited. 


\section{INTRODUCTION}

Climate change is transforming marine ecosystems, causing shifts in species ranges, declines in biodiversity, and changes to ecosystem structure and functioning (Poloczanska et al. 2007). Negative impacts of climate change on marine foundation species or 'ecosystem engineers' (see Jones et al. 1994) that support extensive economic and social wellbeing, such as corals, seagrasses, mangroves, and seaweeds, are likely to be particularly important as these species form the basis of hierarchically organised, species-rich communities (Crain \& Bertness 2006, Schiel \& Foster 2015). Although temperature appears to be a major factor impacting the performance and physiology of marine organisms, climate change encompasses shifts in other environmental factors (i.e. light and nutrient supply) that are important for biological functioning (e.g. biosynthesis and metabolism) and which may act on their own or in combination with temperature (Poloczanska et al. 2007). Multiple forcing factors complicate the ability to predict, test, and interpret the impacts of climate change, creating uncertainty for adaptive management strategies.

Habitat-forming seaweeds are a dominant feature of temperate marine ecosystems and form the basis of productive and diverse communities (Steneck et al. 2002). The south-east region of Australia is an ocean-warming 'hotspot' (Hobday \& Pecl 2014) and encompasses a substantial portion of the Great Southern Reef, one of the most productive temperate reef zones in the world (Bennett et al. 2016). Historically, this region has been warming rapidly since 1950 (Hobday \& Pecl 2014) and is predicted to continue to warm at almost 4 times the global average (Ridgway 2007) due to shifting wind patterns and ocean currents which cause more frequent and intense southerly incursions of the East Australian Current (EAC) (Cai et al. 2005, Oliver et al. 2014). The warm waters of the EAC are oligotrophic, with nitrate $\left(\mathrm{NO}_{3}{ }^{-}\right)$levels typically $<0.5 \mu \mathrm{m}$ and often undetectable (Harris et al. 1987). As seaweeds rely on seasonal nutrient loading for growth and other metabolic processes (Chapman \& Craigie, 1977, Gerard 1982, Wheeler \& Srivastava 1984), increased exposure to EAC conditions are likely to exert both temperature and nutrient stress on canopy-forming kelps.

Macrocystis pyrifera (C. Agardh) is the world's largest and fastest-growing seaweed. It is found from the low intertidal zone to $\sim 30 \mathrm{~m}$ depth in all continents in the southern hemisphere (except Antarctica) and the west coast of Northern America (Graham et al. 2007), where it forms giant kelp 'forests' in cooltemperate waters. Its large-scale distribution is determined by temperatures between 4 and $20^{\circ} \mathrm{C}$ and nitrate concentrations $>1 \mathrm{\mu M} \mathrm{NO}_{3}{ }^{-}$(Schiel \& Foster 2015), while local-scale processes such as grazing, storms, and upwelling events play major roles in driving kelp forest dynamics (Dayton et al. 1984, 1999, Ebeling et al. 1985, Steneck et al. 2002). In Australia, M. pyrifera is confined to the south-eastern part of the continent with the largest population occurring in Tasmania, where it was once a prominent habitat type in eastern Tasmania at depths of 8 to $22 \mathrm{~m}$. However, forests forming dense surface canopies have declined by up to $95 \%$ in the past 60 yr (Johnson et al. 2011), associated with the increased influence of warm oligotrophic EAC waters in the region. In response to the decline, $M$. pyrifera was listed as an endangered marine habitat type under the federal Environmental Protection and Biodiversity Conservation Act 1999 (EPBC Act 1999). The need for better predictions of the future condition of giant kelp forests under climate change is important for management and/or adaptation by humans, and resolving impacts of climate change on the physiological functioning of $M$. pyrifera in eastern Tasmania is one element of this goal.

In general, increasing temperatures lead to reduced fitness in temperate seaweeds (Hatcher et al. 1987, Andersen et al. 2013), and further temperature-driven declines of $M$. pyrifera populations are predicted in south-east Australia (Johnson et al. 2011). However, as light and nutrients also play key roles in seaweed physiology, these factors must be addressed alongside temperature and the potential interactions among them considered. Multifactor climate impact studies with seaweeds reveal both synergistic or antagonistic effects between factors (e.g. among temperature, salinity, UV intensity, desiccation, wave action, and light) on the growth and photosynthesis in Fucus spp. (see review by Wahl et al. 2011) but also show additive effects in some cases (e.g. temperature and UV inhibits $E$. radiata growth and photosynthesis rates; Xiao et al. 2015). Increased influence of EAC waters in Tasmania will likely lead to kelp canopy destabilisation and thinning and thus increased light levels (Wernberg et al. 2010). Adult M. pyrifera engineer the understory light environment, and thus for juvenile sporophytes, light can be either limiting under a thick canopy (Dean \& Jacobsen 1984, Kinlan et al. 2003) or high and photo-inhibitory under a low density or absent canopy (Graham 1996), and therefore, resolving how temperature and light are likely to interact is important. Understanding how these fac- 
tors impact the juvenile sporophyte stage is important as its early survival and growth will ultimately determine productivity and biomass (Graham et al. 2007). Additionally, little is known of M. pyrifera nutrient utilisation dynamics in Tasmania although in California, this species exhibits growth response proportional to nutrient availability (Deysher \& Dean 1986, Dayton et al. 1999). The growth rate hypothesis (Elser et al. 2003) would posit that seaweeds at higher latitudes will be more susceptible to nutrient limitation because selection favours higher instantaneous growth rates in shorter growing seasons, requiring higher P-rich RNA concentrations and a greater reliance on $\mathrm{N}$ for stoichiometry balance to maintain photosynthesis machinery. Assuming DNA tissue concentration is constant, organisms with higher growth potential should have higher RNA:DNA ratios and higher N-limitation thresholds (Dortch et al. 1983, Elser et al. 2003). Thus, it is useful to assess how nutrients and light interact with temperature to affect $M$. pyrifera physiology under climate change scenarios.

This study examines the interaction of temperature, light, and nitrate on the physiology of juvenile M. pyrifera sporophytes. The aims were to test (1) whether the effects of increased temperature on M. pyrifera physiology will be particularly severe in south-east Australia due to synergistic effects of reduced nitrates and increased light due to a decline in canopy cover and (2) whether RNA concentration, and thus RNA:DNA ratios, will correlate with growth rates due to increased protein synthesis.

\section{MATERIALS AND METHODS}

\subsection{Collection and in situ measurements}

Juvenile Macrocystis pyrifera sporophytes (50 to $150 \mathrm{~mm}$ in length) were collected from Fortescue Bay, Tasmania $\left(43.1230^{\circ} \mathrm{S}, 147.9764^{\circ} \mathrm{E}\right)$ in September 2012 at a depth of $\sim 10 \mathrm{~m}$. At the time of collection, in situ water temperature was $\sim 13^{\circ} \mathrm{C}$, and photosynthetically active radiation (PAR) under the canopy was $\sim 30 \mu \mathrm{mol}$ photons $\mathrm{m}^{-2} \mathrm{~s}^{-1}$ (Odyssey PAR logger, Dataflow Systems). The juvenile sporophytes were transported in seawater-filled coolers to the IMAS laboratory facility in Hobart and held at $13^{\circ} \mathrm{C}$ for $24 \mathrm{~h}$ under low light $(12 \mathrm{~h}$ light:12 h dark at $10 \mu \mathrm{mol}$ photons $\mathrm{m}^{-2} \mathrm{~s}^{-1}$ ) to slow respiration and photosynthesis rates and reduce the risk of temperature, oxygen, and nutrient stress (Peckol 1983). During collections, in situ baseline physiology was measured from 3 haphazardly selected juvenile sporophytes using a PAM fluorometer, and an additional 4 juvenile sporophytes were collected for baseline measurements of pigments, chemistry, and nucleic acids back in the laboratory (see Section 2.3).

\subsection{Experimental design and growth conditions}

The response of juvenile M. pyrifera sporophytes to temperature, light, and nitrate levels were determined using a 3-way factorial design, with main effects of temperature $\left(12,17\right.$, and $\left.22^{\circ} \mathrm{C}\right)$, irradiance $\left(6,30\right.$, and $80 \mu \mathrm{mol}$ photons $\left.\mathrm{m}^{-2} \mathrm{~s}^{-1}\right)$, and nitrate concentration ( 0.5 and $3.0 \mu \mathrm{M} \mathrm{NO}_{3}^{-}$). This range of temperatures was approximated to reflect those currently experienced by M. pyrifera in Tasmania $\left(\sim 12^{\circ} \mathrm{C}\right.$ winter and $\sim 18^{\circ} \mathrm{C}$ summer $)$ and projected summer maxima $\left(22^{\circ} \mathrm{C}\right)$ under the highest possible Representative Concentration of Pathways of greenhouse gas emissions (RCP8.5) scenarios at current $\mathrm{CO}_{2}$ loadings (CSIRO and Bureau of Meteorology 2015). The incident irradiance simulated light levels in the field under dense, partial, and absent kelp canopy (Tatsumi \& Wright 2016, Dayton et al. 1999, E. Flukes et al. unpubl. data), while nitrate levels were chosen based on normal (high) and EACinfluenced (low) ranges observed at Maria Island, Tasmania (Rochford 1984).

The juvenile sporophytes were grown for up to $28 \mathrm{~d}$ in the experimental treatments in the laboratory, which is sufficient time to see changes in seaweed growth and elemental stoichiometry (Flukes et al. 2015), with 3 independent replicates of each temperature-irradiance-nitrate combination.

Upon arrival at the laboratory, juvenile M. pyrifera sporophytes were divided between 3 holding tanks containing $0.2 \mu \mathrm{m}$ filtered seawater, aerated, and shaded with flyscreen mesh, and assigned 1 of 3 temperature-controlled rooms. Incremental changes to temperature $\left(\sim 2.0^{\circ} \mathrm{C} \mathrm{d}^{-1}\right)$ were made until experimental target conditions were reached. An earlier pilot trial indicated acute physiological stress in juvenile sporophytes under sudden increases in temperature and light. Consequently, incremental changes to temperature $\left(2^{\circ} \mathrm{C} \mathrm{d}^{-1}\right)$ were made until the 3 experimental target temperatures were reached. After $3 \mathrm{~d}$ acclimation, thalli were haphazardly selected from the tubs, and 2 individuals were placed into each glass beaker $(2000 \mathrm{ml})$ containing growth media and subject to a particular treatment. Thalli were freefloating, as pilot trials showed no difference in physiological performance between vertically oriented 
and free-floating thalli. The media was aerated to ensure sufficient mixing and disturbance of the diffusion boundary layer around thalli. Beakers were shaded by multiple layers of flyscreen to achieve irradiance of $10 \mu \mathrm{mol}$ photons $\mathrm{m}^{-2} \mathrm{~s}^{-1}$. Irradiance was increased for high-light treatments by removal of layers of flyscreen over an additional $2 \mathrm{~d}$ by $10 \mu \mathrm{mol}$ photons $\mathrm{m}^{-2} \mathrm{~s}^{-1} \mathrm{~d}^{-1}$ until the target of $30 \mu \mathrm{mol}$ photons $\mathrm{m}^{-2} \mathrm{~s}^{-1}$ was reached, and similarly more flyscreen was added to achieve the low light treatment of $6.0 \mu \mathrm{mol}$ photons $\mathrm{m}^{-2} \mathrm{~s}^{-1}$. Media was replenished every 2 to $3 \mathrm{~d}$ for the duration of the experiment to ensure nutrient levels were maintained.

Growth media (Wright's Chu \#10 [WC]) comprised autoclaved, nutrient-depleted, $0.2 \mu \mathrm{m}$ filtered seawater with added base stocks of vitamins, trace metals, potassium hydrogen sulphate $\left(\mathrm{K}_{2} \mathrm{HPO}_{4}\right)$, and sodium nitrate $\left(\mathrm{NaNO}_{3}{ }^{-}\right.$) (Guillard \& Lorenzen 1972). Manipulation of nitrate was achieved by modifying the volume of $\mathrm{NaNO}_{3}{ }^{-}$added to WC media to achieve target concentrations, whilst keeping the ratio of phosphorus to nitrate stoichiometrically balanced at 20:1 by also manipulating the addition of $\mathrm{K}_{2} \mathrm{HPO}_{4}$ (Guillard \& Lorenzen 1972), to avoid limitation of macronutrients. Aeration of the media in each beaker was used to promote circulation of media around the thalli, with air passing through a $0.2 \mu \mathrm{m}$ syringe filter to minimise media contamination risk. Temperaturecontrolled rooms were set to 12,17 , and $22^{\circ} \mathrm{C}$, while light was provided by cool white fluorescent tubes (Sylvania 36W/w41) on a 12 h light:12 h dark (L:D) cycle.

\subsection{Physiological measurements}

Physiological responses requiring tissue sacrifice were measured from one of the pair of thalli in each beaker at $T=0 \mathrm{~d}$ ( $T_{0}$ : post-acclimation) and at the end of experiment ( $T_{\text {end }}$ : up to $28 \mathrm{~d}$ after $T_{0}$ ). On both occasions, PAM fluorometry measurements were taken, and then tissue was sacrificed for chlorophyll, tissue chemistry, and nucleic acid analysis. At $T_{0}$, the second thallus was weighed to enable determination of relative growth when the same individual was weighed at the end of the experiment. Once PAM fluorometry was conducted, thalli were cut into sections of 10 to $20 \mathrm{~mm}^{2}$ for nucleic acid analysis and stoichiometric analysis, while larger sections (20 to $40 \mathrm{~mm}^{2}$ ) were required for pigment analysis (see Section 2.5). All sections were handled with gloves, tweezers, and a scalpel after being washed in $\mathrm{dH}_{2} \mathrm{O}$, then patted dry and prepared for storage before pro- cessing. Tissue chemistry sections were immediately placed into a $-20^{\circ} \mathrm{C}$ freezer for further analysis, and pigment sections were immediately frozen in darkness at $-20^{\circ}$. Nucleic acid sections were placed in RNAlater (Ambion), a non-toxic, rapid stabilisation buffer that preserves total tissue RNA and DNA, then frozen at $-20^{\circ} \mathrm{C}$.

\subsection{PAM fluorometry}

Relative photosynthetic performance was estimated from rapid light curves (RLCs) obtained by measuring variable chlorophyll a ( $\mathrm{chl}$ a) fluorescence in photosystem II (PSII) as a function of PAR using a bluelight diving PAM fluorometer (Walz). A 'leaf clip' with closable window was attached to thalli just above the meristematic region to maintain uniform spacing between the fibre optic light source and thallus tissue and to eliminate ambient light interference to ensure consistency of fluorescence measurements. RLCs were generated by an internal PAM software routine where actinic light intensity increased in 8 steps of $10 \mathrm{~s}$ each, measuring effective quantum yield of PSII ( $\left.\phi_{\text {PSII }}\right)$ as a function of PAR at each step. Relative electron transport rate (rETR) was determined by multiplying $\phi_{\mathrm{PSII}}$ by the respective PAR, which estimates the rate of electrons pumped through the photosynthetic chain (Beer et al. 2001). Estimates of electron transport dynamics were determined by plotting rETR against the respective PAR and fitted to a double exponential decay model (Eq. 1).

RLCs were determined twice on single thalli under pre-treatments of ambient light and dark-acclimation ( 15 min or more). Dark-acclimation duration was determined by pilot studies to be $\sim 15 \mathrm{~min}$, after which more time under dark conditions showed no further increases in maximum fluorescence $\left(F_{\mathrm{m}}\right)$ or maximum quantum yield $\left(F_{\mathrm{v}} / F_{\mathrm{m}}\right)$, indicating reoxidation of the electron transport chain and relaxation of the photoprotective mechanisms. Ambient light RLCs reflect the immediate light history and can be affected by ambient irradiance conditions (i.e. cloud cover, canopy shading, water turbidity, etc.), whereas dark-acclimated RLCs indicate the inherent state of the photosystem (Ralph \& Gademann 2005). When conducting PAM fluorometry with a leaf clip, local areas of tissue are subject to saturating pulses of actinic light, so it was ensured that the 2 PAM measurements (i.e. light-acclimated and dark-acclimated) came from different tissue, by moving the PAM leaf clip approximately 1 to $2 \mathrm{~cm}$ from the first measurement position between readings. 
RLCs can be described and compared by characterising the photosynthetic response (raw rETR data) as a function of light, determined by the initial linear response and the region of photoinhibition (Ralph \& Gademann 2005). RLC parameters were derived by fitting the raw data to the Platt et al. (1980) double exponential decay function to calculate maximum electron transport rate $\left(\mathrm{rETR}_{\max }\right)$ and saturating light intensity $\left(E_{\mathrm{k}}\right)$ using the following equation:

$$
P=P_{\mathrm{s}}\left[1-\exp \left(\frac{-\alpha E_{\mathrm{d}}}{P_{\mathrm{s}}}\right)\right] \times \exp \left(\frac{-\beta E_{\mathrm{d}}}{P_{\mathrm{s}}}\right)
$$

where $P$ is the photosynthetic rate (rETR), $\alpha$ is the initial slope before the onset of saturation, $E_{\mathrm{d}}$ is the incident downwelling irradiance of the PAM internal halogen light, $\beta$ characterises the slope region where PSII declines after photoinhibition (Henley 1993), and $P_{\mathrm{S}}$ is a scaling factor defined as the maximum potential rETR. The parameters $\mathrm{rETR}_{\max }$ and $E_{\mathrm{k}}$ were estimated as per the Platt et al. (1980) equation using a nonlinear least-squares function in the ' $\mathrm{R}$ ' software environment ( $v$ 3.0.0) to fit the models. To ensure convergence, the regression model settings were as follows: iterations $=100 ;$ step size $=1 / 1024 ;$ tolerance $=0.00001$; initial seed value for $P=\mathrm{rETR}_{\text {max }}$ derived from raw data, $\alpha=$ slope of linear regression fitted to the first 3 points of raw data (typically in the range 0.7 to 1.0 ).

$F_{\mathrm{v}} / F_{\mathrm{m}}$ was determined from dark-acclimated measurements where minimum fluorescence $\left(F_{0}\right)$ and $F_{\mathrm{m}}$ were used to calculate variable fluorescence $\left(F_{\mathrm{v}}\right)$, then used to determine the intrinsic potential quantum efficiency of PSII.

\subsection{Pigments}

Frozen samples were thawed and patted dry, and 100 to $150 \mathrm{mg}$ of tissue was weighed (to the nearest $0.01 \mathrm{mg}$ ) and placed into a $15 \mathrm{ml}$ vial containing $5 \mathrm{ml}$ of $N, N$-Dimethylformamide (DMF, Sigma Aldrich) to facilitate pigment extraction. Extraction vials were pre-wrapped in aluminium foil, and samples were processed rapidly in a fume hood under low light to avoid pigment damage from ambient light then placed in the freezer under total darkness at $-20^{\circ} \mathrm{C}$ for $96 \mathrm{~h}$ for pigment extraction to occur.

\subsection{Chl $a$ and $C$}

A $3 \mathrm{ml}$ aliquot of pigment extract was pipetted into a centrifuge tube and centrifuged for $8 \mathrm{~min}$ at $8000 \mathrm{rpm}$. Chl $a$ and $c$ content of the supernatant was determined spectrophotometrically (wavelengths: 664.5, 631, and $582 \mathrm{~nm}$ ) using a Dynamica HALO RB-10 Spectrophotometer and processed using UV Detective software (v.1.1). Blanks of $100 \%$ DMF were read every 10 readings. In accordance with manufacturer's instructions, where absorbance read above 1000, supernatant was diluted with DMF until absorbance dropped below 1000. Dilution factor was recorded and factored into the final calculations for pigment concentration. $\mathrm{Chl} a$ and $c$ concentrations were calculated using the recommended absorption coefficients following Inskeep \& Bloom (1985) and Seely et al. (1972).

\subsection{Fucoxanthin}

Fucoxanthin content was determined from the remaining $\sim 2 \mathrm{ml}$ extractant. Aliquots of $2 \mu \mathrm{l}$ of extract were injected using Waters Acquity H-series Ultra High Performance Liquid Chromotography (UPLC) coupled to a Waters Acquity Photodiode Array detector with a Waters Acquity UPLC Ethylene Bridged Hybrid (BEH) C18 column (2.1 mm × $100 \mathrm{~mm} \times 1.7$ $\mu \mathrm{m}$ particles). Mobile phases comprised a gradient mixture of 3 solvents prepared by Merck Chemicals, viz. acetic acid (1\%), acetonitrile, and 80:20 methanol: hexane (Merck). Initial conditions were held for $3.5 \mathrm{~min}$ in a $20 \%$ acetic acid solvent and $80 \%$ acetonitrile solvent, followed immediately by $80 \%$ acetonitrile and $20 \%$ methanol:hexane solvent which was then held for a further $5.5 \mathrm{~min}$, followed by $3 \mathrm{~min}$ re-equilibration to original conditions. The column was held at $35^{\circ} \mathrm{C}$, and the flow rate was $0.35 \mathrm{ml}$ $\min ^{-1}$. The photodiode array detector was monitored continuously over the range 230 to $500 \mathrm{~nm}$. Under these conditions, fucoxanthin eluted at $2.3 \mathrm{~min}$. Initial calibration of the visible ultra-violet response at $440 \mathrm{~nm}$ for fucoxanthin was carried out on a freshly prepared standard solution (Sigma Aldrich) made up at $1.26 \mu \mathrm{g} \mathrm{ml}^{-1}$ in methanol. Chromatograms were extracted at $440 \mathrm{~nm}$ from the raw data using Waters TargetLynx v.4.1 software, and the area of the fucoxanthin peak was recorded and converted to $\mathrm{mg} \mathrm{ml}^{-1}$ fucoxanthin before conversion to $\mathrm{mg} \mathrm{g}^{-1}$ wet weight.

\subsection{Elemental stoichiometry $(\mathrm{N}, \mathrm{C})$}

Frozen samples were thawed, patted dry, and then freeze-dried, with weighing every 12 to $24 \mathrm{~h}$ (to $0.01 \mathrm{mg}$ ) until deemed anhydrous when no further weight loss was detected. Samples were ground and homogenised in a mortar and pestle, and $\sim 5 \mathrm{mg}$ of 
powder was placed into tin cups, which were folded gently prior to analysis. Carbon, nitrogen, and isotope signatures $\left(\delta^{13} \mathrm{C}\right.$ and $\left.\delta^{15} \mathrm{~N}\right)$ were measured using a Thermo gas chromatograph coupled to a Finnigan Mat Delta $\mathrm{S}$ isotope radio mass spectrometer in continuous flow mode at CSIRO, Hobart. Results were calculated as follows and are presented in standard sigma notation:

$$
\delta^{13} \mathrm{C} \text { or } \delta^{15} \mathrm{~N}(\%)=\left[\frac{R_{\text {sample }}}{R_{\text {standard }}}-1\right]
$$

where $R=\frac{{ }^{13} \mathrm{C}}{{ }^{12} \mathrm{C}}$ or $\frac{{ }^{15} \mathrm{~N}}{{ }^{14} \mathrm{~N}}$. Standards were replaced and run every 12 cycles with Pee Dee Belemnite (PDB) used as a standard for carbon and air as a standard for nitrogen.

\subsection{Nucleic acids}

Absolute RNA and DNA levels were determined to obtain RNA:DNA ratios as a proxy for 'growth potential' by extraction of total nucleic acids and RNA/ DNA components from a single tissue sample (Flukes et al. 2015). A piece of algal tissue preserved in RNAlater weighing between 1 and $5 \mathrm{mg}(\mathrm{w} / \mathrm{w})$ was patted dry, weighed and homogenised in a roundbottom $2 \mu \mathrm{l}$ centrifuge tube (Eppendorf Safe-lock microcentrifuge tube) using a drill pestle in an extraction buffer comprising $500 \mu \mathrm{l}$ urea $(4 \mathrm{M}), 1 \%$ sodium dodecyl sulphate (SDS), trisodium citrate $(1 \mathrm{mM})$, sodium chloride $(0.2 \mathrm{M})$, and $5 \mu \mathrm{l}$ of proteinase $\mathrm{K}$ (Urea/SDS buffer). To ensure stabilisation of nucleic acid, digestion of RNAses by proteinase $\mathrm{K}$ and complete cell lysis, the homogenised solution was held at $37^{\circ} \mathrm{C}$ for $10 \mathrm{~min}$ then placed immediately onto ice. Impurities (e.g. chlorophyll, phenolic compounds, salts, and detergents in urea/SDS) were removed by vortexing the solution with $750 \mu \mathrm{l}$ of ammonium acetate, followed by centrifugation for $5 \mathrm{~min}$ at $14100 \times g$. The resulting supernatant was decanted into a $1.5 \mathrm{ml}$ tube to which $700 \mu \mathrm{l}$ isopropanol was added, and the tube was gently inverted 40 times to aid complete mixing of total nucleic acids (tNA) and isopropanol. The total tNA was pelletised by centrifuge (10 min at $14100 \times$ $g$ ), and the pellet was washed twice in a $75 \%$ ethanol (EtOH) solution, then resuspended in $200 \mu \mathrm{l}$ molecular grade $\mathrm{H}_{2} \mathrm{O}$ at $55^{\circ} \mathrm{C}$ for 10 min and separated into two $100 \mu$ l aliquots.

To isolate RNA, a solution of $80 \mu \mathrm{l}$ molecular grade water, 5 $\mu$ l DNAse (DNase I - Biolabs M0303L) with $20 \mu \mathrm{l}$ buffer (New England Biolabs B0303S) was added to 1 aliquot for total DNA digestion, whilst $100 \mu \mathrm{l}$ water and $5 \mu \mathrm{l}$ RNAse (Sigma Aldrich R6148-
25ML) was added to the second aliquot to digest RNA for total DNA isolation. To facilitate digestion, aliquots were incubated at $37^{\circ} \mathrm{C}$ for 20 min then stabilised on ice. Isolated nucleic acids were stabilised and extracted by vortexing (10 s) with $400 \mu$ lof urea/SDS buffer, vortexing (15 s) and centrifuging $(10 \mathrm{~min}$ at $14000 \times g)$ with $200 \mu \mathrm{l}$ ammonium acetate $(7.5 \mathrm{M})$, decanting supernatant into $1.5 \mathrm{ml}$ tubes, and binding and pelletising with isopropanol as described in the previous step. RNA and DNA pellets were washed twice in $75 \% \mathrm{EtOH}$ and resuspended into $100 \mu \mathrm{l}$ of molecular grade water (RNA) and EB buffer (DNA). RNA and DNA concentrations were measured by fluorescence assays using a Quibit assay probe and fluorometer and expressed as total RNA and total DNA ( $\mu \mathrm{g} \mathrm{g}^{-1}$ wet weight tissue). These values were used to calculate the RNA:DNA ratios.

\subsection{Growth}

Absolute growth and relative growth rates were determined from wet weight measures after first drying the specimen on absorbent paper towel before placing on the scale. Daily relative growth rate $R$ was calculated as

$$
R=\frac{\log _{\mathrm{e} 2} W-\log _{\mathrm{e} 1} W}{{ }_{2} T-{ }_{1} T}
$$

where $W$ is weight in grams, and $T$ is time in days.

\subsection{Statistical analyses}

Tissue necrosis during the experiment led to poor tissue condition in some juvenile sporophytes, which resulted in unrealistic physiological measurements (PSII, chemistry, and nucleic acid), and a number of individuals, particularly from high-temperature and high-light treatments, were not able to be measured for certain metrics. Therefore, the planned fully factorial univariate analyses testing for temperature $x$ light $\times$ nitrate effects after $28 \mathrm{~d}$ of experimental treatments were not possible for some metrics. Data were partitioned into 3 different analyses:

(1) at low temperature $\left(12^{\circ} \mathrm{C}\right), 2$-way ANOVAs determined the effects of light (fixed: 6, 30, and $80 \mu \mathrm{mol}$ photons $\mathrm{m}^{-2} \mathrm{~s}^{-1}$ ) and nitrate (fixed: 0.5 and $3.0 \mu \mathrm{M}$ $\mathrm{NO}_{3}{ }^{-}$) at $T_{0}$ and $T_{\text {end }}$ on PSII, pigments, elemental chemistry, nucleic acids, and relative growth rates;

(2) at $T_{0}, 3$-way ANOVAs tested the effects of temperature (fixed: 12,17 , and $22^{\circ} \mathrm{C}$ ), light (fixed: 6 and 
$30 \mu \mathrm{mol}$ photons $\mathrm{m}^{-2} \mathrm{~s}^{-1}$, i.e. $80 \mu \mathrm{mol}$ photons $\mathrm{m}^{-2} \mathrm{~s}^{-1}$ was not included), and nitrate (0.5 and $3.0 \mu \mathrm{M} \mathrm{NO}_{3}{ }^{-}$). The same analyses were done at $T_{\text {end }}$ except for treatments subject to high water temperature $\left(22^{\circ} \mathrm{C}\right)$, which was dropped for all response variables except for pigments for which sufficient material was available;

(3) at $T_{\text {end }}$ moderate light (30 $\mu \mathrm{mol}$ photons $\mathrm{m}^{-2} \mathrm{~s}^{-1}$ ) occurred across all levels of temperature and nitrate, and thus a 2-way ANOVA was conducted across temperature and nitrates for all metrics except pigments, which were incorporated into the second set of analyses.

Assumptions of ANOVA were checked and transformations determined using the Box-Cox method. Tukey's HSD post-hoc tests were conducted where there were significant overall results to determine the source of differences between treatment groups.

The multivariate physiological response to treatments was analysed using permutational multivariate ANOVA (PERMANOVA) at both $T_{0}$ and $T_{\text {end }}$ to determine overall treatment effects on joint distributions of response variables. In 5 instances, determination of $\mathrm{rETR}_{\max }$ and $E_{\mathrm{k}}$ was not possible due to degraded tissue, and so these variables were not included in the multivariate analyses. The design was unbalanced since 1 replicate could not be included because of missing nucleic acid data. PERMANOVA was conducted on Gower similarity matrices (Gower 1971) generated from raw data, with 9999 permutations to calculate pseudo F-statistics. Terms with negative estimates of components of variation were pooled (Anderson et al. 2008).

\section{RESULTS}

\subsection{Short-term response to acclimation: low-temperature treatment $\left(12^{\circ} \mathrm{C}\right)$}

Following short-term acclimation (i.e. at $T_{0}$ ) at $12^{\circ} \mathrm{C}$, 2-way ANOVA revealed no effects of nitrate or light separately, nor any light $x$ nitrate interaction, for $F_{\mathrm{v}} / F_{\mathrm{m}}$, pigments, nitrogen concentration, or nucleic acids (Table $1 \mathrm{~A}$, Figs. 1-4). $\mathrm{rETR}_{\max }$ and $E_{\mathrm{k}}$ were significantly higher at high light compared to low light (80 > $6 \mu \mathrm{mol}$ photons $\mathrm{m}^{-2} \mathrm{~s}^{-1}$; Fig. 1). Juvenile sporophytes in moderate-light ( $30 \mu \mathrm{mol}$ photons $\mathrm{m}^{-2} \mathrm{~s}^{-1}$ ) treatments had significantly higher carbon concentration (compared to other light

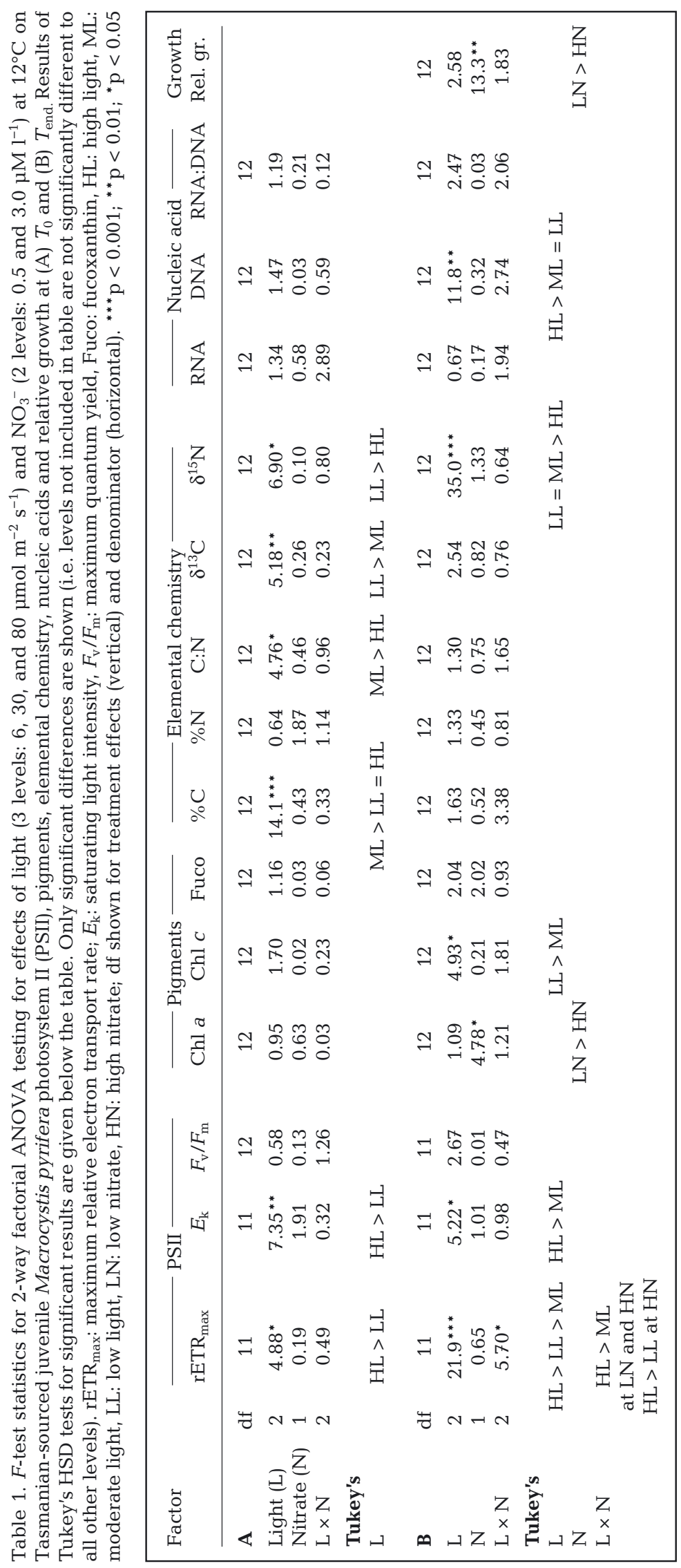




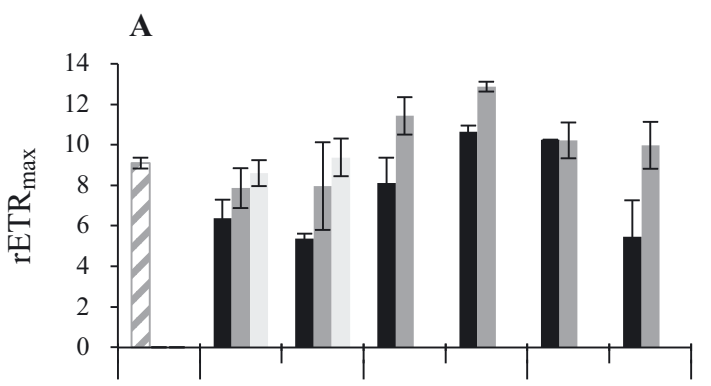

B
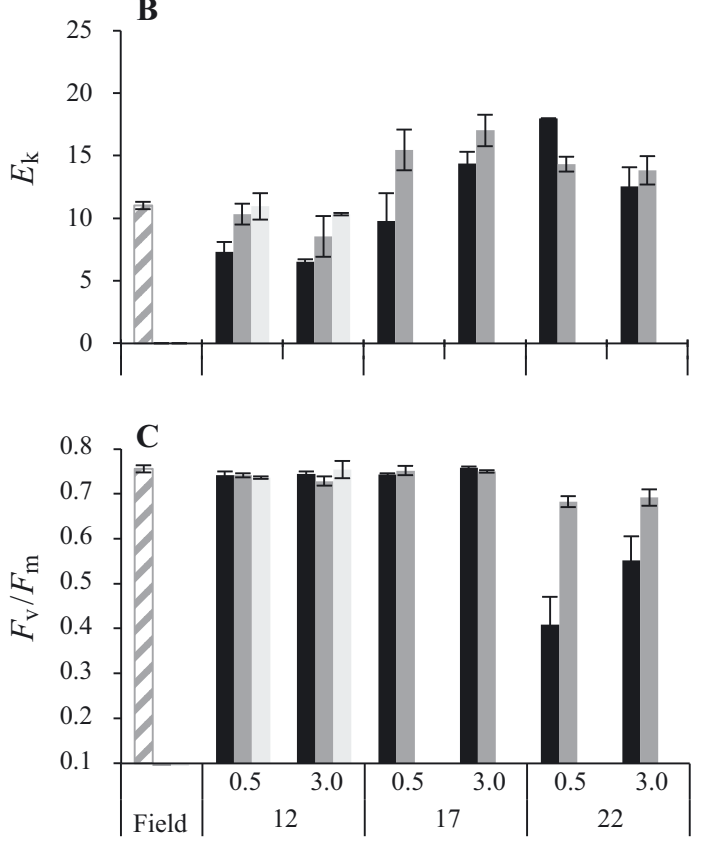

Treatment

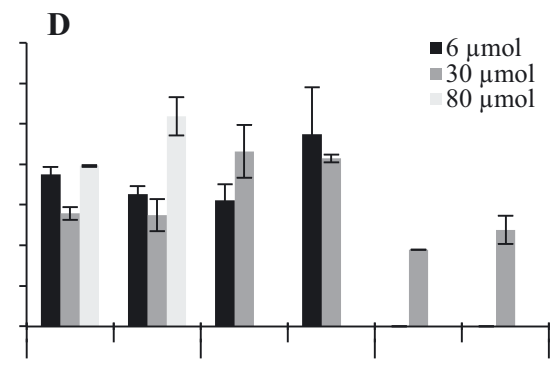

$\mathbf{E}$
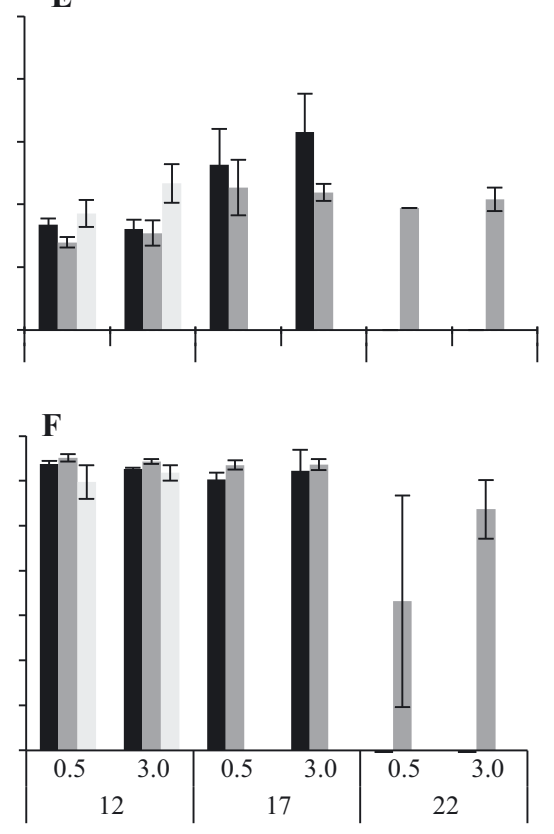

$\mathrm{NO}_{3}{ }^{-}\left(\mu \mathrm{M} \mathrm{l}^{-1}\right)$, temperature $\left({ }^{\circ} \mathrm{C}\right)$

Fig. 1. PSII traits of juvenile Macrocystis pyrifera sporophytes originating from Tasmania measured in situ (field) and after exposure to experimental treatments of all combinations of temperature (3 levels), nitrate (2 levels), and light ( 3 levels, in $\mu$ mol photons $\mathrm{m}^{-2} \mathrm{~s}^{-1}$ ) following acclimation to experimental conditions (A-C) at $T_{0}$ and (D-F) after $\leq 28 \mathrm{~d}$ in experimental treatments $\left(T_{\text {end }}\right)$. Plots show $(\mathrm{A}, \mathrm{D})$ maximum relative electron transport rate $\left(\mathrm{rETR}_{\max }\right) ;(\mathrm{B}, \mathrm{E})$ saturating light intensity $\left(E_{\mathrm{k}}\right) ;(\mathrm{C}, \mathrm{F})$ maximum quantum yield $\left(F_{\mathrm{v}} / F_{\mathrm{m}}\right)$; as derived from dark-adapted rapid light curves measured by PAM fluorometry. Bars indicate mean values $\pm \mathrm{SE}(\mathrm{n}=3)$

treatments) and $\mathrm{C}: \mathrm{N}$ ratio (compared to high light only; Table 1A, Fig. 3). In low-light treatments, stable isotope ratios of sporeling tissue were less negative for $\delta^{13} \mathrm{C}$ (compared to moderate light) and $\delta^{15} \mathrm{~N}$ (compared to high light; Table 1A, Fig. 3).

\subsection{Short-term response to acclimation: multiple temperature treatments}

Three-way ANOVAs (excluding the high-light treatment) showed no treatment effects at $T_{0}$ for chl $a$, fucoxanthin, and $\delta^{15} \mathrm{~N}$ (Table 2A, Figs. $2 \& 3$ ). $\mathrm{rETR}_{\max }$ and $E_{\mathrm{k}}$ were significantly higher at moderate light (vs. low) and $17^{\circ} \mathrm{C}$ (vs. $12^{\circ} \mathrm{C}$ ) (Table 2A, Fig. 1).
At $22^{\circ} \mathrm{C}$, there were no further increases in PSII traits but significantly lower $F_{\mathrm{v}} / F_{\mathrm{m}}$ under low light (Table 2A, Fig. 1), indicating a reduction in PSII integrity at high temperature and low light (temperature $\times$ light interaction). Under low light, chl $C$ was significantly higher (Table 2A, Fig. 2) while carbon concentration and $\mathrm{C}: \mathrm{N}$ ratios were lower, associated with a less negative carbon isotope signature (Table 2A, Fig. 3). At high temperature $\left(22^{\circ} \mathrm{C}\right)$, juvenile sporophytes subject to low-light treatments had higher nitrogen concentrations (Table 2A, Fig. 3) but were lower in RNA content (Table 2A, Fig. 4) than when grown under moderate light. RNA concentrations were higher at $12^{\circ} \mathrm{C}$ (vs. $22^{\circ} \mathrm{C}$, but only at low light; temperature $\times$ light interaction) and $0.5 \mu \mathrm{M}$ 

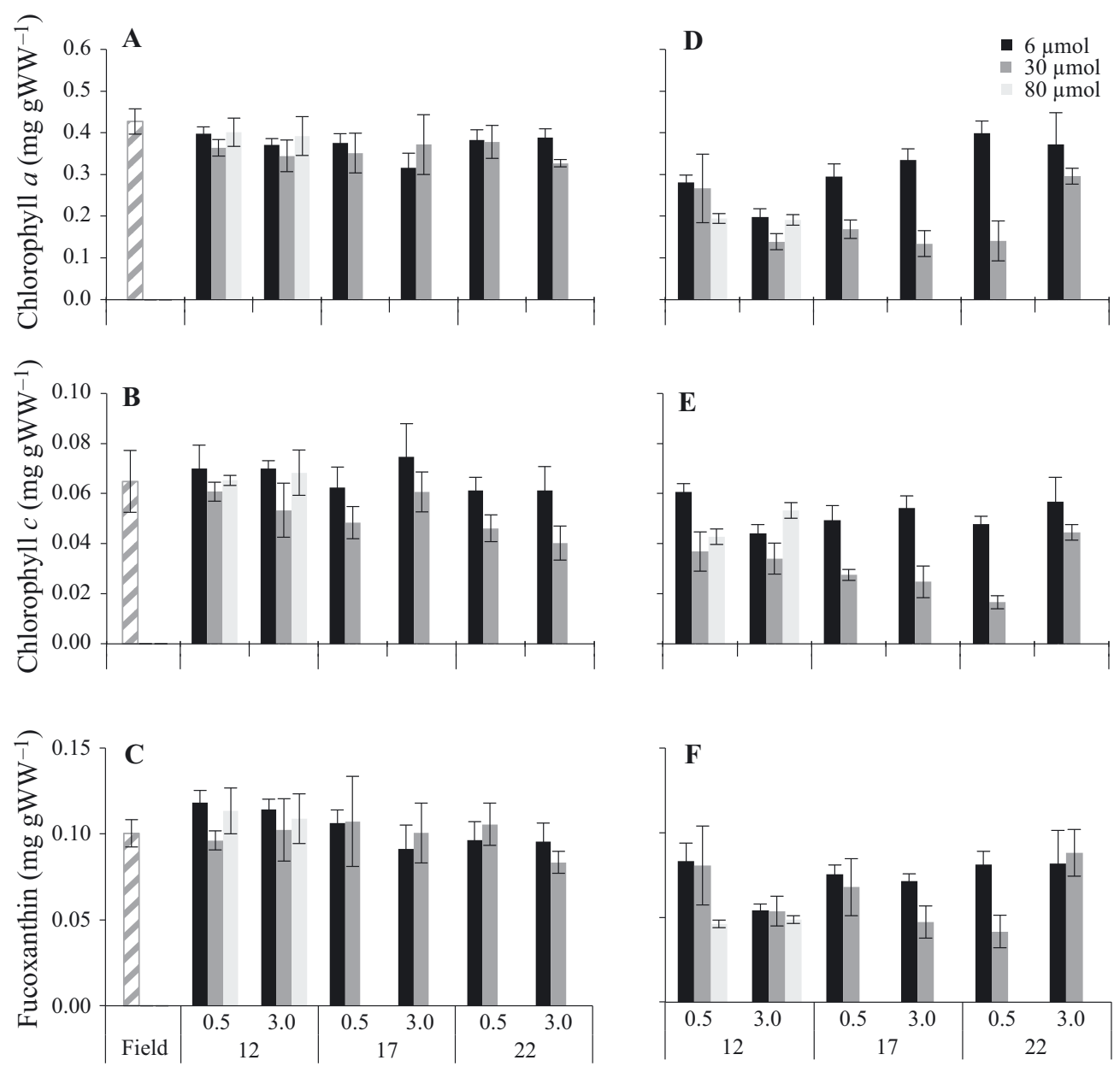

Treatment

$\mathrm{NO}_{3}{ }^{-}\left(\mu \mathrm{M} \mathrm{l}^{-1}\right)$, temperature $\left({ }^{\circ} \mathrm{C}\right)$

Fig. 2. As in Fig. 1 but for pigment content. Plots show tissue concentrations of $(A, D)$ chl $a_{i}(B, E)$ chl $C_{i}(C, F)$ fucoxanthin. Bars indicate mean values $\pm \mathrm{SE}(\mathrm{n}=3)$

$\mathrm{NO}_{3}{ }^{-}$(vs. $3.0 \mu \mathrm{M}$, but only in moderate light; nitrate $\times$ light interaction; Table 2A, Fig. 4). There were significant main effects affecting absolute DNA concentration (light: $30>6 \mu \mathrm{mol}$ photons $\mathrm{m}^{-2} \mathrm{~s}^{-1}$ ) and RNA:DNA ratios (light and temperature: $6>30 \mu \mathrm{mol}$ photons $\mathrm{m}^{-2} \mathrm{~s}^{-1}$ and $22>17^{\circ} \mathrm{C}$; Table 2A, Fig. 4).

\subsection{Longer-term responses: low temperature treatment $\left(12^{\circ} \mathrm{C}\right)$}

\subsubsection{PSII and pigments}

At $T_{\text {end }}$, juvenile sporophytes grown at low temperature $\left(12^{\circ} \mathrm{C}\right)$ revealed no treatment effects for $F_{\mathrm{v}} / F_{\mathrm{m}}$ or fucoxanthin (Table 1B, Figs. 1 \& 2). rETR $\max$ was significantly highest under the high-light-highnitrate combination (light $\times$ nitrate interaction), while
$E_{\mathrm{k}}$ was significantly higher when juvenile sporophytes were grown under high light than at moderate light levels (Table 1B, Fig. 1). Pigment concentrations were higher under low-nitrate treatments (chl a only) and low-light treatments compared to moderate light (chl $c$ only; Table 1B, Fig. 2).

\subsubsection{Growth, nucleic acids, and tissue chemistry}

At $T_{\text {end }}$ and $12^{\circ} \mathrm{C}$, no treatment effects were found for $\delta^{15} \mathrm{C}$, RNA concentration, or RNA:DNA ratios (Table 1B, Figs. 3 \& 4). Across all light treatments, high light yielded more negative $\delta^{15} \mathrm{~N}$ signatures and higher concentrations of DNA (Table 1B, Figs. 3 \& 4) compared to other light treatments. Surprisingly, relative growth was significantly higher under the lowest nitrate treatment (Table 1B, Fig. 4). 

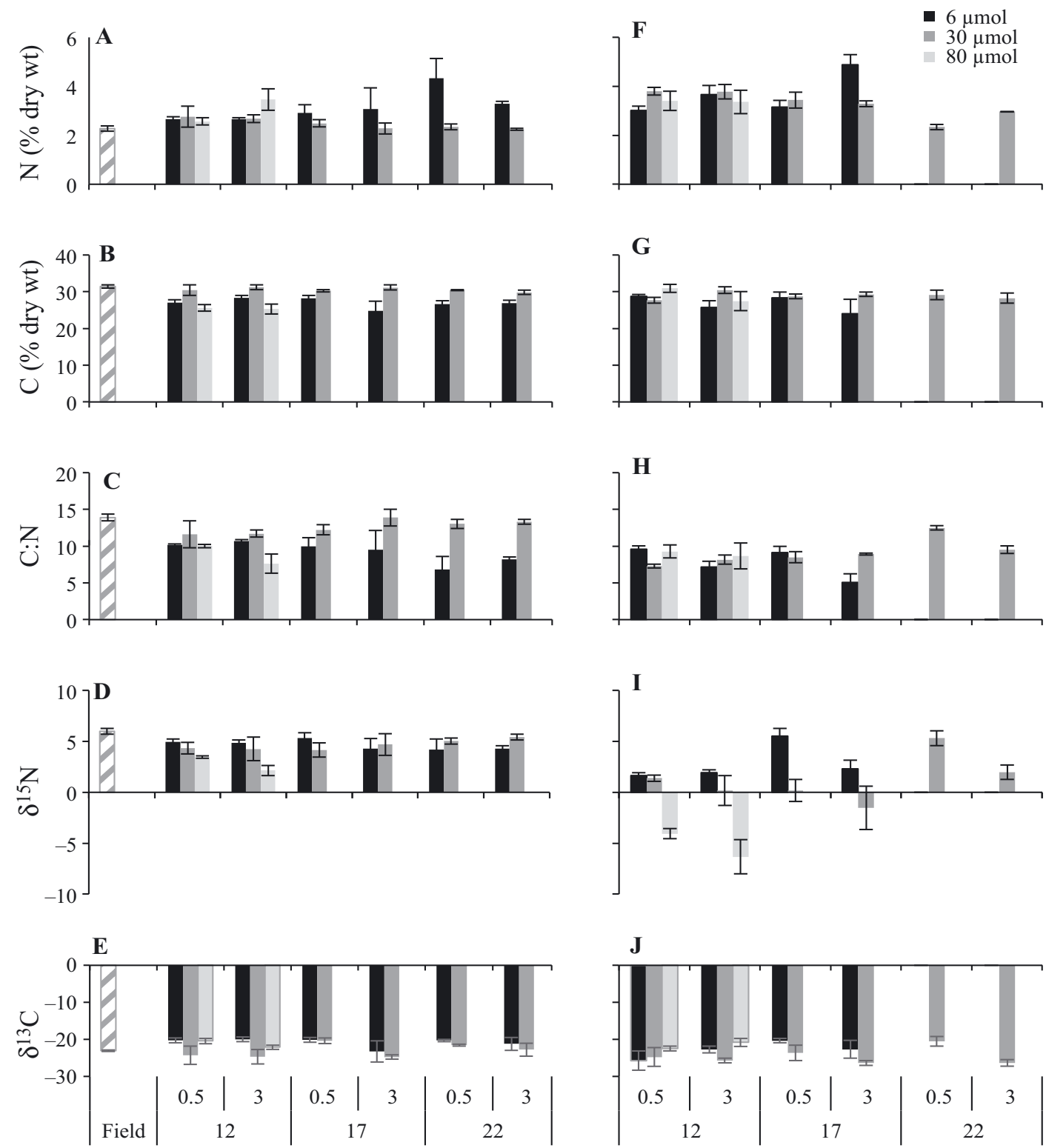

Treatment

$\mathrm{NO}_{3}{ }^{-}\left(\mu \mathrm{M}^{-1}\right)$, temperature $\left({ }^{\circ} \mathrm{C}\right)$

Fig. 3. As in Fig. 1 but for elemental chemistry. Plots show tissue proportions of $(A, F)$ nitrogen, $(B, G)$ carbon, $(C, H)$ carbon: nitrogen ratio, $(\mathrm{D}, \mathrm{I})$ stable isotopic signature of $\delta^{15} \mathrm{~N}$ and $(\mathrm{E}, \mathrm{J}) \delta^{13} \mathrm{C}$. Bars indicate mean values $\pm \mathrm{SE}(\mathrm{n}=3)$

\subsection{Longer-term responses: multiple temperature treatments}

\subsubsection{PSII and pigments}

At the end of the experiment, 3-way ANOVA showed no treatment effects for $F_{\mathrm{v}} / F_{\mathrm{m}}$ (Table 2B, Fig. 1). Temperature effects on $\mathrm{rETR}_{\max }\left(17>12^{\circ} \mathrm{C}\right)$ were restricted to moderate light levels only (temperature $\times$ light interaction), whilst the effect of temperature on $E_{\mathrm{k}}$ was not dependent on the light level (Table 2B, Fig. 1). Low light yielded significantly higher $\mathrm{chl} a$ and $c$ concentrations, but there was no such change in fucoxanthin levels (Table 2B, Fig. 2). Higher concentrations of chl a and fucoxanthin at $22^{\circ} \mathrm{C}$ (vs. $12^{\circ} \mathrm{C}$ ) only occurred at high nitrate concentrations (temperature $\times$ nitrate interaction). $\mathrm{Chl} C$ concentration was higher at $12^{\circ} \mathrm{C}$ (vs. $22^{\circ} \mathrm{C}$ ) when nitrate levels were low and was higher at $0.5 \mu \mathrm{M} \mathrm{NO}_{3}{ }^{-}$treatments (vs. $3.0 \mu \mathrm{m}$ ) but only at $22^{\circ} \mathrm{C}$ (temperature $\times$ nitrate interaction, Table $2 \mathrm{~B}$, Fig. 2). 

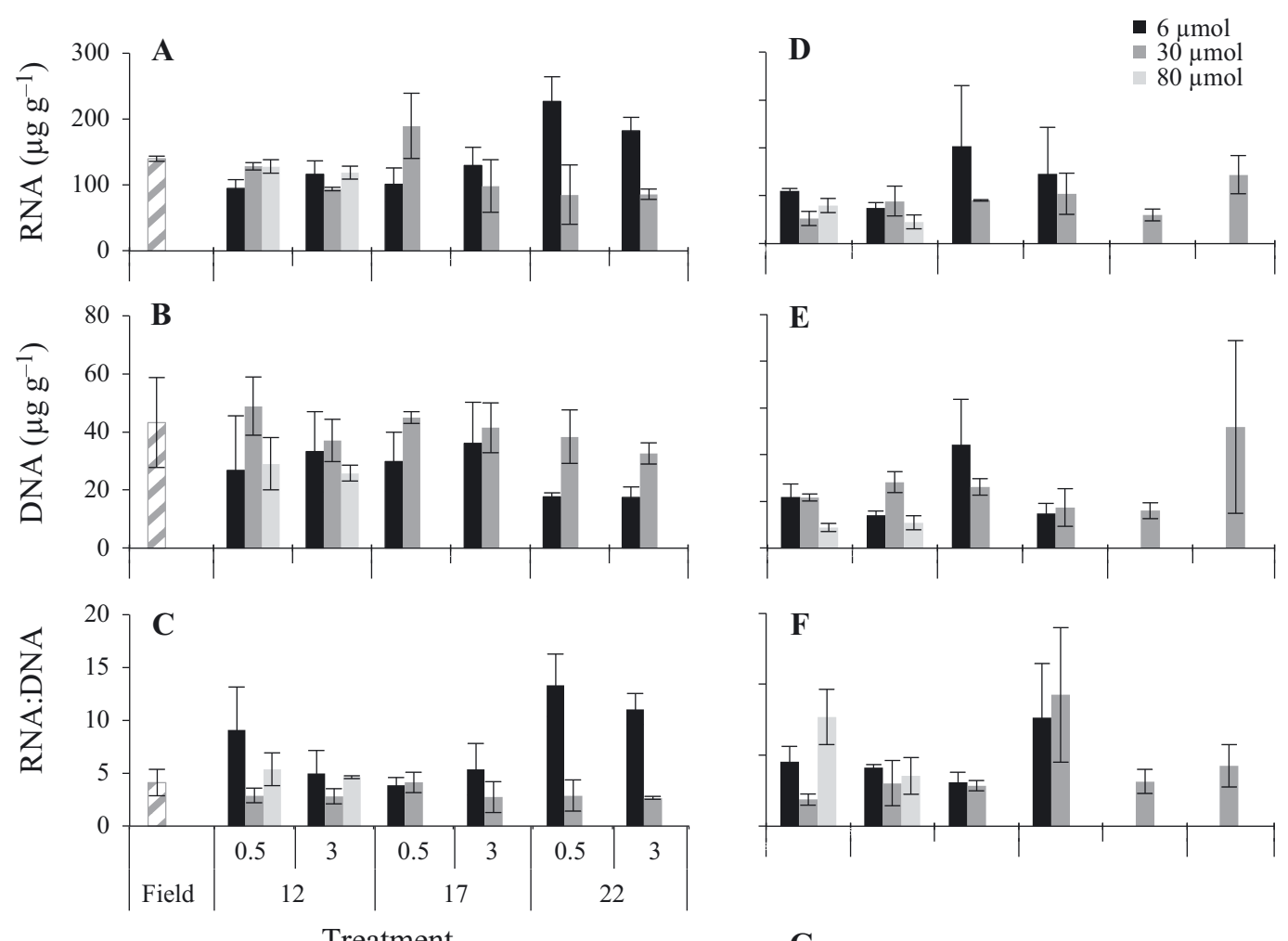

Treatment

$\mathrm{NO}_{3}{ }^{-}\left(\mu \mathrm{M} \mathrm{l} l^{-1}\right)$, temperature $\left({ }^{\circ} \mathrm{C}\right)$

Fig. 4. As in Fig. 1 but for nucleic acid content and RNA: DNA ratios. Plots show tissue concentrations of $(A, D)$ RNA, $(\mathrm{B}, \mathrm{E}) \mathrm{DNA},(\mathrm{C}, \mathrm{F}) \mathrm{RNA}$ :DNA ratios and $(\mathrm{G})$ relative growth rate. Bars indicate mean values $\pm \mathrm{SE}(\mathrm{n}=3)$

\subsubsection{Growth, nucleic acids, and tissue chemistry}

Three-way ANOVA revealed no treatment effects on nucleic acid levels (Table 2B, Fig. 4). Carbon concentration was significantly higher at $30 \mu \mathrm{mol}$ photons $\mathrm{m}^{-2} \mathrm{~s}^{-1}$ light treatments (vs. $6 \mu \mathrm{mol}$ photons $\mathrm{m}^{-2} \mathrm{~s}^{-1}$ ) but only at low nitrate availability (Table 2B, Fig. 3). Nitrate treatments significantly influenced nitrogen concentration $\left(3.0>0.5 \mu \mathrm{M} \mathrm{NO}_{3}{ }^{-}\right)$and $\mathrm{C}: \mathrm{N}$ ratio $\left(0.5>3.0 \mu \mathrm{M} \mathrm{NO}_{3}^{-}\right)$in low-light treatments only (light $\times$ nitrate interaction). Additionally, the $\mathrm{C}: \mathrm{N}$ ratio was significantly higher at $30 \mu \mathrm{mol}$ photons $\mathrm{m}^{-2} \mathrm{~s}^{-1}$ (vs. $6 \mu \mathrm{mol}$ photons $\mathrm{m}^{-2} \mathrm{~s}^{-1}$ ) but only at high nitrate levels (light $\times$ nitrate interaction; Table 2B, Fig. 3). Significant temperature and nitrate effects

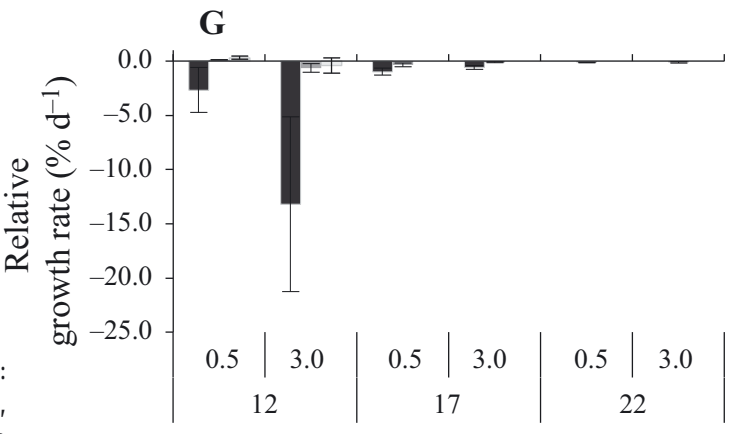

Treatment

$\mathrm{NO}_{3}{ }^{-}\left(\mu \mathrm{M} \mathrm{1^{-1 }}\right)$, temperature $\left({ }^{\circ} \mathrm{C}\right)$

were additive for relative growth rates which were higher at $12^{\circ} \mathrm{C}$ and at low nitrate levels (Table 2B, Fig. 4).

\subsection{Longer-term responses: moderate light treatment}

At $T_{\text {end, }}$ under moderate light levels (30 $\mu \mathrm{mol}$ photons $\mathrm{m}^{-2} \mathrm{~s}^{-1}$ ), 2-way ANOVA showed no treatment effects on carbon or nucleic acid concentrations (Table 3, Figs. $3 \& 4$ ). $\mathrm{rETR}_{\max }$ and $E_{\mathrm{k}}$ increased with temperature from 12 to $17^{\circ} \mathrm{C}$ but not to $22^{\circ} \mathrm{C}$ and were associated with significantly lower $F_{\mathrm{v}} / F_{\mathrm{m}}$ at $22^{\circ} \mathrm{C}$, suggesting down-regulation and compromised integrity 


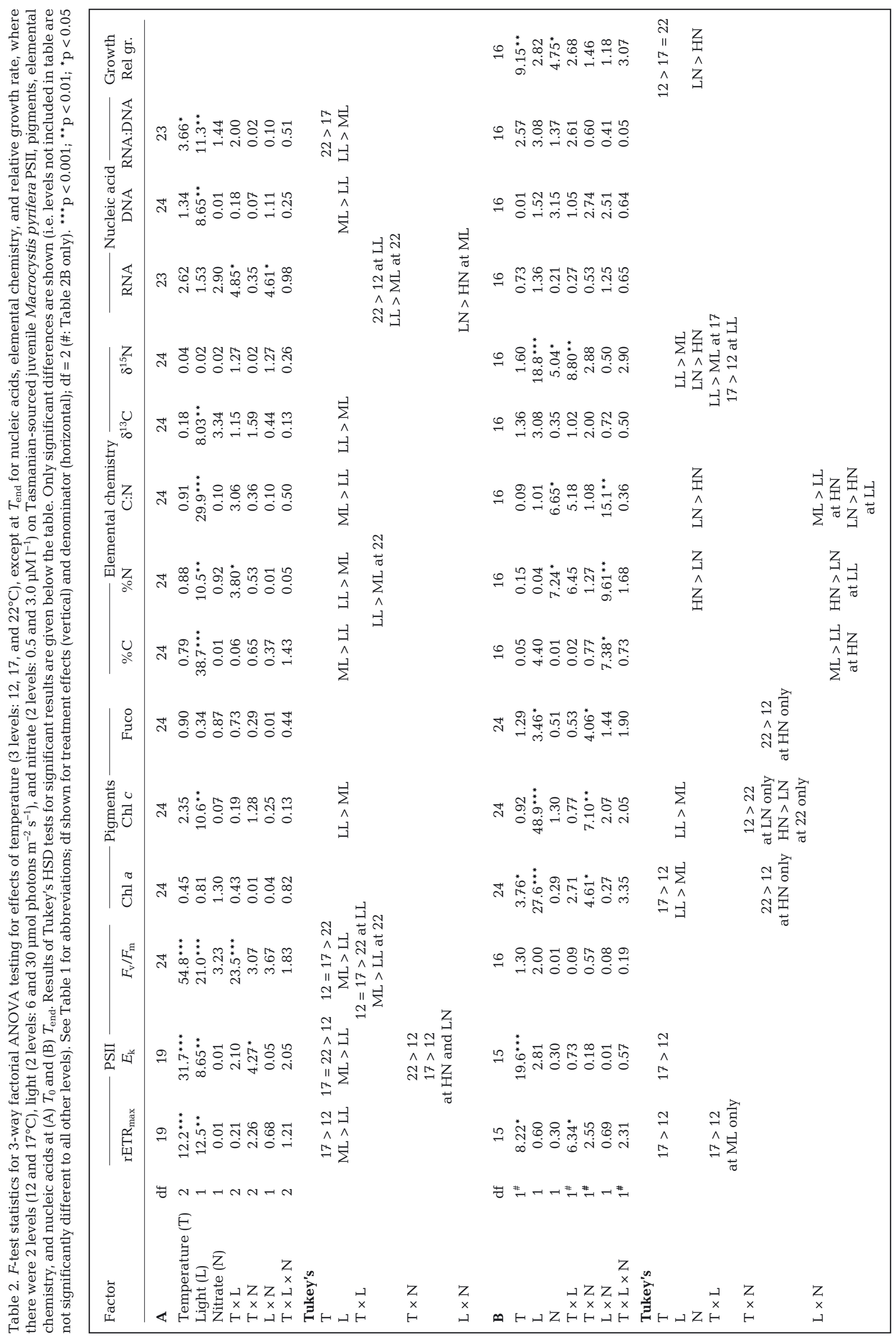


of photosystem II (Table 3, Fig. 1). In low-nitrate treatments, there were temperature effects on nitrogen concentration $\left(12=17>22^{\circ} \mathrm{C}\right)$ and the $\mathrm{C}: \mathrm{N}$ ratio $(22>$ $12=17^{\circ} \mathrm{C}$ : significant temperature $\times$ nitrate interaction), while at $22^{\circ} \mathrm{C}$, nitrate levels affected the $\mathrm{C}: \mathrm{N}$ ratio $\left(0.5>3.0 \mu \mathrm{M} \mathrm{NO}_{3}{ }^{-}\right)$. $\delta^{15} \mathrm{~N}$ values were less negative under $22^{\circ} \mathrm{C}$ (vs. at 12 and $17^{\circ} \mathrm{C}$ ) and $0.5 \mu \mathrm{M} \mathrm{NO}_{3}{ }^{-}$ (vs. 3.0: Table 3, Fig. 3). Relative growth was significantly lower at $22^{\circ} \mathrm{C}$ (vs. 12 and $17^{\circ} \mathrm{C}_{\text {; }}$ Table 3, Fig. 4).

\subsection{Multivariate phenotype response}

Three-way PERMANOVA revealed significant variation in the multivariate physiological response of juvenile $M$. pyrifera sporophytes at both $T_{0}$ and $T_{\text {end }}$ due to interaction effects of various combinations, although there was no evidence of a 3-way interaction (Table 4). Short-term $\left(T_{0}\right)$ multivariate response differentiated 12 and $17^{\circ} \mathrm{C}$ from $22^{\circ} \mathrm{C}$ under low light only (a temperature $\times$ light interaction: Pseudo- $F_{1,21}=2.29, \mathrm{p}=0.036$ ). The first 2 eigenvalue correlations of the canonical analysis of principle coordinates (CAP) were $76 \%$ and $29 \%$ and suggested that the variables contributing most to the variation under different treatments were $F_{\mathrm{v}} / F_{\mathrm{m}}$, DNA, and accessory pigments, which increased in the direction of benign environments, whereas RNA and elemental chemistry increased in the direction of stressful environments (Fig. 5). By the end of the experiment ( $T_{\text {end }}$, the multivariate response indicated significant 2-way interactions involving all 3 factors (temperature $\times$ nitrate: pseudo- $F_{2,21}=2.89, \mathrm{p}=0.004$; temperature $\times$ light: pseudo- $F_{1,21}=3.14, \mathrm{p}=0.005$; and nitrate $\times$ light: pseudo- $F_{2,21}=2.36, p=0.007$ ) (Fig. 6). The first 4 eigenvalue correlations of the CAP were $96,89,80$, and $77 \%$ and suggested that the variables contributing most to the variation under different treatments were relative growth rate and $F_{\mathrm{v}} / F_{\mathrm{m}}$ and carbon concentration, which increased in favourable environments, whilst RNA, pigments, and DNA increased under stressful environments.

\section{DISCUSSION}

This study found that differential temperature, light, and nitrate levels lead to significant responses in a range of variables describing the physiology of juvenile Macrocystis pyrifera sporophytes. Warming seawater negatively affected multiple traits in juvenile sporophytes, consistent with previous studies in which elevated temperatures reduce growth and im-

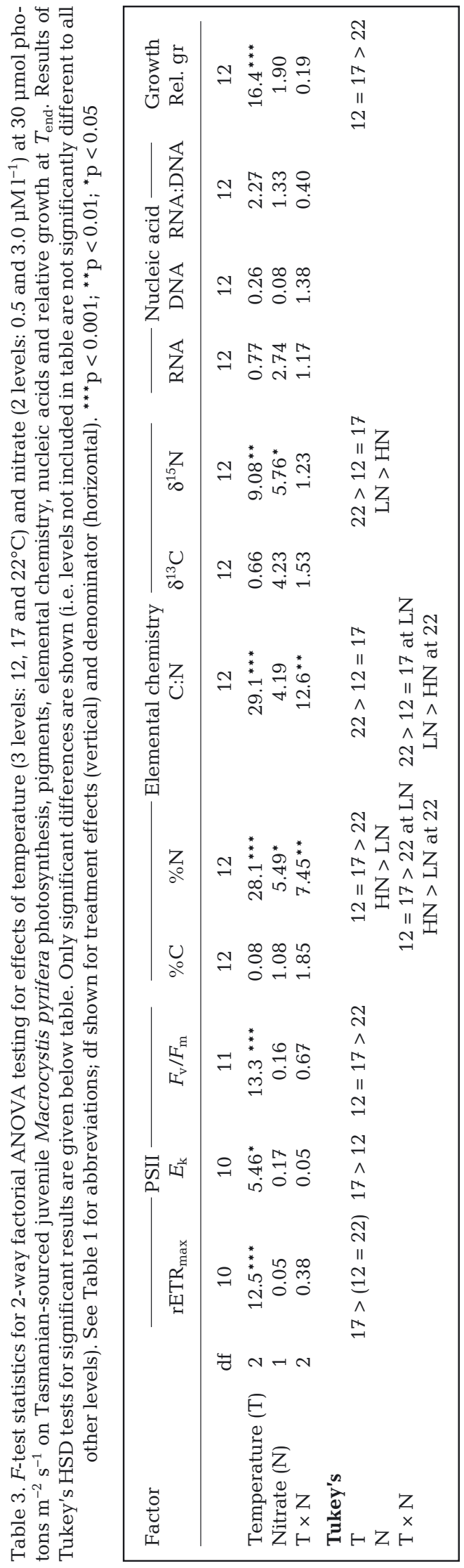


Table 4. PERMANOVA results comparing the multivariate phenotype of Macrocystis pyrifera between orthogonal treatments of temperature $\left(12,17\right.$ and $\left.22^{\circ} \mathrm{C}\right)$, light $\left(10\right.$ and $30 \mu \mathrm{mol}$ photons $\left.\mathrm{m}^{-2} \mathrm{~s}^{-1}\right)$, and nitrate $\left(0.5\right.$ and $\left.3.0 \mu \mathrm{M} \mathrm{NO}_{3}{ }^{-}\right)$at $T_{0}$ and $T_{\text {end }}$. Interaction terms with negative coefficients of variation were dropped from the analysis. Significant $p$ values given in bold

\begin{tabular}{|c|c|c|c|c|c|c|c|c|}
\hline \multirow[t]{2}{*}{ Source of variation } & \multirow[b]{2}{*}{ df } & \multirow[b]{2}{*}{ MS } & \multirow{2}{*}{$\begin{array}{l}T_{0} \\
\text { Pseudo- } F\end{array}$} & \multirow[b]{2}{*}{$\mathrm{p}$} & \multirow[b]{2}{*}{ df } & \multicolumn{3}{|c|}{$T_{\text {end }}$} \\
\hline & & & & & & MS & Pseudo- $F$ & $\mathrm{p}$ \\
\hline Temperature $(\mathrm{T})$ & 2 & 821.33 & 3.3019 & 0.002 & 2 & 677.74 & 4.198 & $<0.001$ \\
\hline Light (L) & 2 & 1786.5 & 7.1821 & $<0.001$ & 2 & 1118.1 & 6.926 & $<0.001$ \\
\hline Nitrate (N) & 1 & 388.74 & 1.5628 & 0.183 & 1 & 514.88 & 3.189 & 0.014 \\
\hline $\mathrm{T} \times \mathrm{L}$ & 2 & 570.49 & 2.2935 & 0.036 & 1 & 507.21 & 3.142 & 0.010 \\
\hline $\mathrm{T} \times \mathrm{N}$ & - & - & - & - & 2 & 466.36 & 2.889 & 0.008 \\
\hline $\mathrm{L} \times \mathrm{N}$ & - & - & - & - & 2 & 380.96 & 2.360 & 0.016 \\
\hline $\mathrm{T} \times \mathrm{L} \quad \mathrm{N}$ & - & - & - & - & - & - & - & - \\
\hline Residual & 33 & 248.75 & & & 21 & 161.43 & & \\
\hline
\end{tabular}

pair biological function in most temperate seaweeds (Harley et al. 2012). Additionally, light and nitrates provided further impacts either independently, additively, or synergistically. These results illustrate the impacts on physiological processes that will likely shape the performance and distribution of $M$. pyrifera under future climate change in south-eastern Australia whilst showing that globally distributed species exhibit locally evolved nutrient utilisation dynamics.

\subsection{Additive effects of temperature and light on M. pyrifera condition}

Different temperature and light treatments caused significant variation in multiple physiological vari- ables. Chronic macroscopic tissue deterioration and sporeling mortality in high temperature $\left(22^{\circ} \mathrm{C}\right)$ and high light $\left(80 \mu \mathrm{mol}\right.$ photons $\left.\mathrm{m}^{-2} \mathrm{~s}^{-1}\right)$ treatments were observed. Relationships between temperature and light and PSII are well documented for photoautotrophs, as PSII-associated enzyme-catalysed reactions (RuBisCO and Calvin cycle activity) are thermally labile (Davison \& Davison 1987) and electron transfer rates are light-dependent (Ramus 1981). This kind of change in enzymatic activity might explain the general pattern of increases in $\mathrm{rETR}_{\max }$ and $E_{\mathrm{k}}$ with increasing temperature $\left(12\right.$ to $\left.17^{\circ} \mathrm{C}\right)$ and increasing light. Conversely, high temperature stress impairs biochemical pathways (Davison \& Pearson 1996) and can cause denaturation of proteins and degradation of thylakoid membrane properties (Ma-

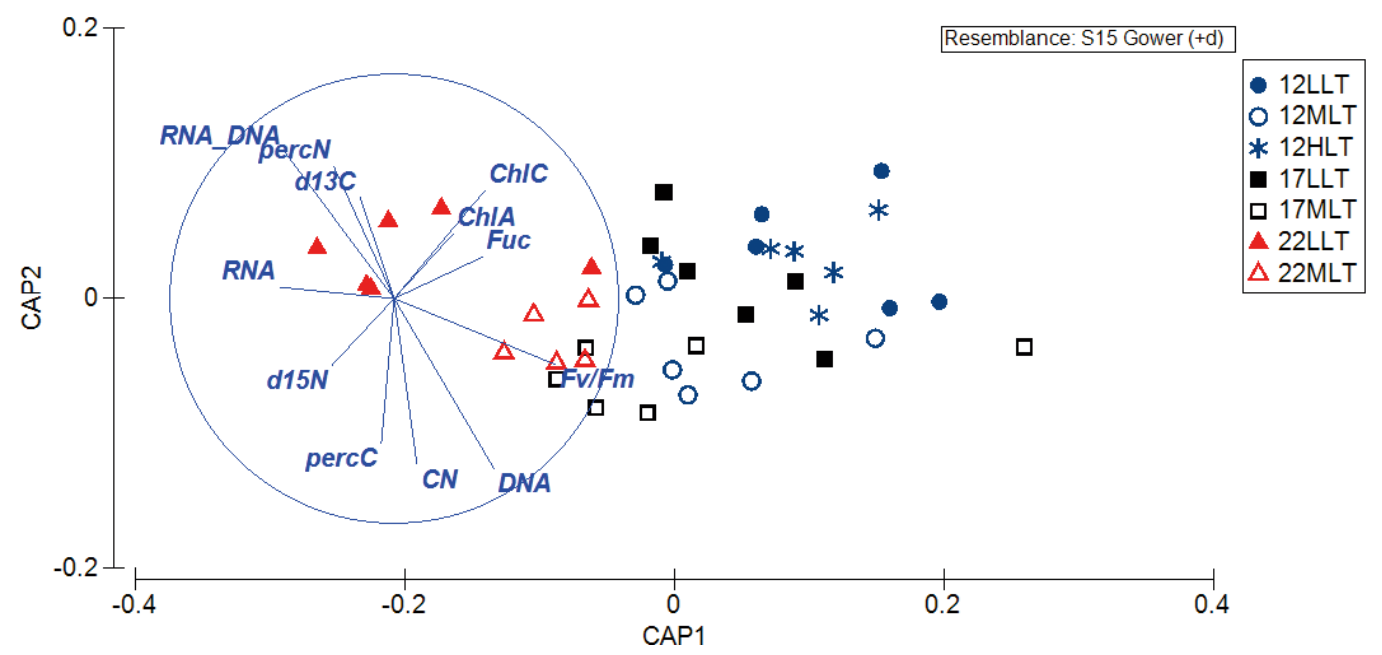

Fig. 5. Canonical analysis of principal coordinates (CAP) ordination of physiological response metrics of Macrocystis pyrifera to combined effects of temperature and light (based on a Gower similarity matrix of raw data for 12 traits) post-acclimation $\left(T_{0}\right)$. The CAP analysis was constrained to differentiate among treatments of temperature and light levels and shows clustering of light treatments and distinct separation of temperature effects. The vector overlay represents Pearson correlations between the ordination axes and direction and magnitude of trait influence. Symbols: temperature $\left(12,17\right.$, and $\left.22^{\circ} \mathrm{C}\right)$ and light (low: LLT, medium: MLT, high: HLT) 


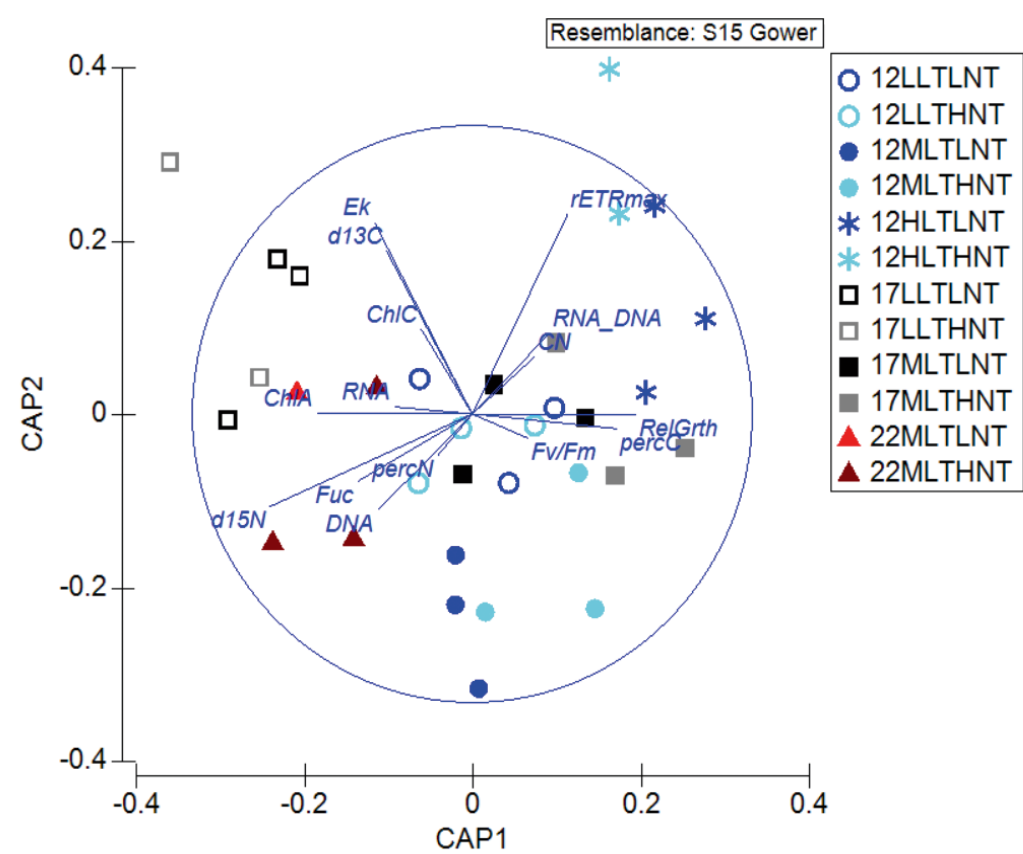

Fig. 6. CAP ordination of physiological response metrics of Macrocystis pyrifera to combined effects of temperature, nitrates and light (based on a Gower similarity matrix of raw data for 12 traits) after longer-term exposure to experimental treatments $\left(T_{\text {end }}\right)$. The CAP analysis was constrained to differentiate among treatments of the different combinations of temperature, nitrate and light levels. The vector overlay represents Pearson correlations between the ordination axes and direction and magnitude of trait influence. Symbols: temperature $\left(12,17\right.$, and $22^{\circ} \mathrm{C}$ ), light (low: LLT, medium: MLT, high: HLT) and nitrate (low: LNT, medium: MNT, high: HNT)

heswari et al. 1999), inhibiting key photoprotective processes such as the production of chaperones (heatshock proteins; Wahl et al. 2011). Moreover, nutrient uptake and gas exchange capabilities are impacted by high temperature, causing downregulation of photosynthetic activity (i.e. a drop in $\mathrm{rETR}_{\max }$ and $E_{\mathrm{k}}$ ), impairment of PSII (reduced $F_{\mathrm{v}} / F_{\mathrm{m}}$ ) (Andersen et al. 2013), and ultimately tissue degradation and mortality as was observed at $22^{\circ} \mathrm{C}$. Light energy absorption is independent of temperature and this energy is diverted into production of proteins, enzymes, and photoprotective mechanisms (Franklin et al. 2003). Light absorbed in excess of photosynthetic demand generates reactive oxygen species that alter the permeability of chloroplast membranes and loss of electron transport capacity (Kyle et al. 1984), disrupting carbon fixation and protein synthesis (Murata et al. 2007), leading to chronic photoinhibition and photodamage where photoprotection fails to mitigate photoinactivation (Franklin et al. 2003).

In the high-light treatments, the increased energetic requirements of photosynthetic activity at temperatures above $12^{\circ} \mathrm{C}$ may have undermined photo- protective capabilities, leading to rapid mortality in these treatment combinations. This follows temperate algal assemblages that exhibit increased compensating irradiance and reduced primary productivity and respiration under elevated temperature and irradiance (Tait \& Schiel 2013). These findings highlight the vulnerability of M. pyrifera at temperatures above $12^{\circ} \mathrm{C}$ under a reduced canopy where irradiance can fall within the range of 30 to $280 \mu \mathrm{mol}$ photons $\mathrm{m}^{-2} \mathrm{~s}^{-1}$ in Tasmanian kelp forests (Tatsumi \& Wright 2016) and depends on depth, season, and degree of canopy loss.

Conversely, in low-light conditions, investment in pigment synthesis can lead to an 'energy crisis', where energy is diverted from carbohydrate and lipid production to producing light-harvesting pigments (Falkowski \& LaRoche 1991). In this context, the results suggest a synergistic interaction between temperature and light in that short-term exposure (at $T_{0}$ ) to low light and high temperature at the same time quickly led to impaired PSII function (evidenced by low $F_{\mathrm{v}} / F_{\mathrm{m}}$ ) and significantly greater pigment content (the only determinable metric) in tissue subject to low light compared to moderate light. This suggests an increased vulnerability to ocean warming for $M$. pyrifera recruits in low-light environments such as dense canopy understory, at depth, or locations subject to high sediment loads.

Elevated RNA:DNA ratios under high temperature and low light were also associated with impaired PSII (low $\left.F_{\mathrm{v}} / F_{\mathrm{m}}\right)$ after short-term exposure $\left(T_{0}\right)$ and reflected both an overall increase in RNA concentration and a decrease in DNA levels in treatments with low light. This association between PSII and nucleic acid levels may indicate elevated RNA synthesis of protective proteins in response to temperature-induced photosynthetic stress (as found in corals: Hauri et al. 2010) and/or low-light stress where downregulation of $\mathrm{RuBisCO}$ gene expression, transcription, and protein production is associated with lower cellular DNA concentrations, as has been identified in cucumber leaves (Sun et al. 2014). The nature of association between RNA:DNA and $F_{\mathrm{v}} / F_{\mathrm{m}}$ found in M. pyrifera was contrary to that found in juvenile Phyllospora comosa (Flukes et al. 2015), where a precondition for elevated RNA:DNA ratios was a healthy, functioning PSII (high $F_{\mathrm{v}} / F_{\mathrm{m}}$ ). These differences are possibly attributable to the extremely different light 
environments in which these species proliferate, with $P$. comosa occurring in much shallower waters than M. pyrifera.

In the context of the growth rate hypothesis, there was no evidence to support any relationship between RNA:DNA ratio and lineal growth relationship. This reflects the finding that ratios could change with changes in either the absolute concentration of DNA as found in Phyllospora (Flukes et al. 2015), RNA, or both. Variable DNA concentration is known in plants and seaweeds and can be influenced by cell packing density (Dortch et al. 1983), increasing cell size or cell wall thickness (Kraemer \& Chapman 1991), and size of chloroplasts (Rauwolf et al. 2010), characteristics that were undetectable by the measurements. Consequently, these results support that RNA:DNA ratio may be a more useful indicator of recent stress as RNA synthesises for stress-related protein complexes. Identification and quantification of particular stress proteins (i.e. heat-shock proteins) using qPCR methods could be used to indicate the type and severity of stress within populations.

\subsection{Additive effects of temperature and nitrates on $M$. pyrifera growth}

Sporeling growth rates were highest at low temperature and low nitrate levels. Lower growth rates at temperatures above $12^{\circ} \mathrm{C}$ suggest a temperature 'growth boundary' (van den Hoek 1982) between 12 and $17^{\circ} \mathrm{C}$ for M. pyrifera in Fortescue Bay. Hence, it is probable that sustained positive temperature anomalies such as the recent $130 \mathrm{~d}$ heatwave event in south-east Australia (Hobday et al. 2016, E. Oliver pers. comm.) restrict opportunity for sporeling growth and development.

Annual variation of ocean nitrate levels in southeastern Australia generally follow a seasonal trend, ranging from $\sim 0.5 \mu \mathrm{M} \mathrm{NO}_{3}{ }^{-}$and sometimes undetectable levels during the mid-late summer growth season to up to $\sim 3.0 \mu \mathrm{M} \mathrm{NO}_{3}{ }^{-}$in the winter (Harris et al. 1987). M. pyrifera and other kelps can actively regulate nitrogen uptake, assimilation, storage, and use and display locally adapted nitrogen-utilisation strategies (Gagné et al. 1982, Stephens \& Hepburn 2016), although relative to other Laminarian species, M. pyrifera has poor capacity for nitrogen storage (Gerard 1982, 1997). Interestingly, juvenile M. pyrifera sporophytes in low-nitrate treatments had higher relative growth rates, whilst those in highnitrate treatments displayed preference for uptake and storage of $\mathrm{N}$ (higher $\mathrm{N}$ concentrations and more negative ${ }^{15} \mathrm{~N}$ signatures) rather than growth per se. Juvenile sporophytes with higher growth rates had lower nitrogen tissue concentrations, indicating that nitrogen use outstripped replenishment rates, which is typical of Laminarians in low-nitrate conditions (Gerard 1982). However, this does not explain the observed lower growth rates in high-nitrate treatments. Plastic response to stressors via the coupling of physiology and morphology is well documented in kelps (Druehl \& Kemp 1982, Fowler-Walker et al. 2006). Resource acquisition influences morphology in macroalgae, and nutrient stress (low ambient nutrients) may trigger a shift in resource allocation to thallus growth, increasing total surface area to volume ratio and improving nutrient uptake kinetics (Hein et al. 1995). Plants subjected to nutrient starvation can shift growth allocation from leaves to roots (Hirose \& Kitajima 1986), demonstrating resourcedriven changes to morphology. An inverse relationship between nutrient availability and growth has also been described in unicellular marine algae where nitrogen deprivation leads to increased competition between carbon fixation and $\mathrm{N}$ assimilation (Hipkin et al. 1983). This observation is contrary to results for Californian $M$. pyrifera, where growth was limited at yearly minima $\left(2 \mu \mathrm{M} \mathrm{NO}_{3}{ }^{-}\right)$but not limited at yearly maxima ( $\left.8 \mu \mathrm{M} \mathrm{NO}_{3}{ }^{-}\right)$in experimental conditions (Deysher \& Dean 1986, Dayton et al. 1999). This distinction between different populations of $M$. pyrifera provides some evidence that nutrient utilisation dynamics in kelp can be locally adapted and that sporophyte development may be in part triggered by seasonal environmental cues, the timing of which has implications for sporophyte fitness (Kinlan et al. 2003).

\subsection{The future: efficacy of a multifactor approach}

This study emphasises the importance of multifactor approaches to determining species and ecosystem response to climate change. Marine climate change studies up until recently have been predominantly temperature-focused (Harley et al. 2006) and have shown that temperature is clearly important for $M$. pyrifera and other marine species. However, this study demonstrates that effects of ocean warming may be substantially altered when there is simultaneous change in other environmental factors, demonstrating the importance of multifactor approaches in climate-change studies. Further to this, multivariate approaches to assessing physiology are crucial for holistic organismal-level insights into perform- 
ance effects. Based on the lack of support for the growth rate hypothesis and the unexpected inverse relationship between relative growth and nitrogen treatment levels, it can be argued that predictions derived from simplified and generalised approaches, such as RNA:DNA ratios and relative growth rates, may come with high levels of uncertainty (Schiel \& Foster 2015).

Yet a further layer of complexity is associated with 'ecosystem engineers' such as kelp whereby biotic structures modify the abiotic environment, altering conditions for recruitment, which in turn may influence patch dynamics and stability (Dayton et al. 1984, Jones et al. 1994, Steneck et al. 2002). It is likely that the treatment effects observed here will differ for adult and microscopic stages, as is the case in other species of brown algae (Wahl et al. 2011). Hence, more research into the impacts of climate change on other stages is required to determine if and how populations may adapt. Future research must also consider genetic and non-genetic drivers that determine adaptability (Schiel \& Foster 2015), such as genetic diversity and phenotypic plasticity (Reusch 2014). Nevertheless, juvenile sporophytes are an important link in sustaining $M$. pyrifera populations, and as demonstrated here, they exhibit negative responses and susceptibility across a range of physiological parameters. At the very least, temperature, canopy destabilisation (increased light), and disruption of nutrient regimes are certain to provide further distributional declines in M. pyrifera. Examining multiple physiological traits allows for a more comprehensive interpretation of the effects of climate change on overall physiology compared to predictions based on one or a few types of metrics.

Acknowledgements. This research was supported by funds awarded to C.J. and J.W. from the Australian Research Council (DP1096573). C.M. was supported by the UTAS PhD program and received scholarship support from the Institute for Marine and Antarctic Studies, University of Tasmania. We also thank Emma Flukes, Masayuki Tatsumi, and Rebecca Mueller for assistance in the field and laboratory.

\section{LITERATURE CITED}

Andersen GS, Pedersen MF, Nielsen SL (2013) Temperature acclimation and heat tolerance of photosynthesis in Norwegian Saccharina latissima (Laminariales, Phaeophyceae). J Phycol 49:689-700

Anderson MJ, Gorley RN, Clarke KR (2008) PERMANOVA+ for PRIMER: guide to software and statistical methods. PRIMER-E, Plymouth, UK

Beer S, Björk M, Gademann R, Ralph PJ (2001) Measurements of photosynthetic rates in seagrasses. In: Short FT,
Coles RG (eds) Global seagrass research methods. Elsevier, Amsterdam, p 183-198

Bennett S, Wernberg T, Connell SD, Hobday AJ, Johnson CR, Poloczanska ES (2016) The 'Great Southern Reef': social, ecological and economic value of Australia's neglected kelp forests. Mar Freshw Res 67:47-56

Cai W, Shi G, Cowan T, Bi D, Ribbe J (2005) The response of the Southern Annular Mode, the East Australian Current, and the southern mid-latitude ocean circulation to global warming. Geophys Res Lett 32:94-97

Chapman ARO, Craigie JS (1977) Seasonal growth in Laminaria longicruris: relations with dissolved inorganic nutrients and internal reserves of nitrogen. Mar Biol 40: 197-205

* Crain CM, Bertness MD (2006) Ecosystem engineering across environmental gradients: implications for conservation and management. Bioscience 56:211-218

CSIRO and Bureau of Meteorology (2015) Climate change in Australia. Information for Australia's natural resource management regions: technical report. www.climatechangeinaustralia.gov.au/en/publications-library/technicalreport/

Davison IR, Davison J (1987) The effect of growth temperature on enzyme activities in the brown alga Laminaria saccharina. Br Phycol J 22:77-87

Davison IR, Pearson GA (1996) Stress tolerance in intertidal seaweeds. J Phycol 32:197-211

* Dayton PK, Currie V, Gerrodette T, Keller BD, Rosenthal R, Tresca DV (1984) Patch dynamics and stability of some California kelp communities. Ecol Monogr 54:253-289

* Dayton PK, Tegner MJ, Edwards PB, Riser KL (1999) Temporal and spatial scales of kelp demography: the role of oceanographic climate. Ecol Monogr 69:219-250

* Dean TA, Jacobsen FR (1984) Growth of juvenile Macrocystis pyrifera (Laminariales) in relation to environmental factors. Mar Biol 83:301-311

* Deysher LE, Dean TA (1986) In situ recruitment of sporophytes of the giant kelp, Macrocystis pyrifera (L.) CA Agardh: effects of physical factors. J Exp Mar Biol Ecol 103:41-63

* Dortch Q, Roberts T, Clayton J, Ahmed S (1983) RNA/DNA ratios and DNA concentrations as indicators of growth rate and biomass in planktonic marine organisms. Mar Ecol Prog Ser 13:61-71

* Druehl LD, Kemp L (1982) Morphological and growth responses of geographically isolated Macrocystis integrifolia populations when grown in a common environment. Can J Bot 60:1409-1413

Ebeling AW, Laur DR, Rowley RJ (1985) Severe storm disturbances and reversal of community structure in a southern California kelp forest. Mar Biol 84:287-294

Elser JJ, Acharya K, Kyle M, Cotner J and others (2003) Growth rate-stoichiometry couplings in diverse biota. Ecol Lett 6:936-943

Falkowski PG, LaRoche J (1991) Acclimation to spectral irradiance in algae. J Phycol 27:8-14

Flukes EB, Wright JT, Johnson CR (2015) Phenotypic plasticity and biogeographic variation in physiology of habitat-forming seaweed: response to temperature and nitrate. J Phycol 51:896-909

F Fowler-Walker MJ, Wernberg T, Connell SD (2006) Differences in kelp morphology between wave sheltered and exposed localities: morphologically plastic or fixed traits? Mar Biol 148:755-767

Franklin LA, Osmond CB, Larkum AWD (2003) Photoinhibi- 
tion, UV-B and algal photosynthesis. In: Larkum AWD, Douglas SE, Raven JA (eds) Photosynthesis in algae. Springer, p 351-384

* Gagné JA, Mann KH, Chapman ARO (1982) Seasonal patterns of growth and storage in Laminaria longicruris in relation to differing patterns of availability of nitrogen in the water. Mar Biol 69:91-101

* Gerard VA (1982) Growth and utilization of internal nitrogen reserves by the giant kelp Macrocystis pyrifera in a low-nitrogen environment. Mar Biol 66:27-35

Gerard VA (1997) The role of nitrogen nutrition in hightemperature tolerance of the kelp Laminaria saccarina (Chromophyta). J Phycol 33:800-810

Gower JC (1971) A general coefficient of similarity and some of its properties. Biometrics 27:857-871

Graham MH (1996) Effect of high irradiance on recruitment of the giant kelp Macrocystis (Phaeophyta) in shallow water. J Phycol 32:903-906

Graham MH, Vasquez JA, Buschmann AH (2007) Global ecology of the giant kelp Macrocystis. Oceanogr Mar BiolAnnu Rev 45:39-88

Guillard RRL, Lorenzen CJ (1972) Yellow-green algae with chlorophyllid C. J Phycol 8:10-14

*Harley CDG, Hughes AR, Hultgren KM, Miner BG and others (2006) The impacts of climate change in coastal marine systems. Ecol Lett 9:228-241

*Harley CDG, Anderson KM, Demes KW, Jorve JP, Kordas RL, Coyle TA, Graham MH (2012) Effects of climate change on global seaweed communities. J Phycol 48: 1064-1078

Harris G, Nilsson C, Clementson L, Thomas D (1987) The water masses of the East Coast of Tasmania: seasonal and interannual variability and the influence on phytoplankton biomass and productivity. Aust J Mar Freshwater Res 38:569-590

Hatcher BG, Kirkman H, Wood WF (1987) Growth of the kelp Ecklonia radiata near the northern limit of its range in Western Australia. Mar Biol 95:63-73

Hauri C, Fabricius KE, Schaffelke B, Humphrey C (2010) Chemical and physical environmental conditions underneath mat- and canopy-forming macroalgae, and their effects on understorey corals. PLOS ONE 5:e12685

Hein M, Pedersen M, Sand-Jensen K (1995) Size-dependent nitrogen uptake in micro- and macroalgae. Mar Ecol Prog Ser 118:247-253

Henley WJ (1993) Measurement and interpretation of photosynthetic light response curves in algae in the context of photoinhibition and diel changes. J Phycol 29: 729-739

*Hipkin CR, Thomas RJ, Syrett PJ (1983) Effects of nitrogen deficiency on nitrate reductase, nitrate assimilation and photosynthesis in unicellular marine algae. Mar Biol 77: 101-105

Kirose T, Kitajima K (1986) Nitrogen uptake and plant growth I. Effect of nitrogen removal on growth of Polygonum cuspidatum. Ann Bot 58:479-486

Hobday AJ, Pecl GT (2014) Identification of global marine hotspots: sentinels for change and vanguards for adaptation action. Rev Fish Biol Fish 24:415-425

* Hobday AJ, Alexander LV, Perkins SE, Smale DA and others (2016) A hierarchical approach to defining marine heatwaves. Prog Oceanogr 141:227-238

Inskeep WP, Bloom PR (1985) Extinction coefficients of chlorophyll $a$ and $b$ in $N, N$-dimethylformamide and $80 \%$ acetone. Plant Physiol 77:483-485
Johnson CR, Banks SC, Barrett NS, Cazassus F and others (2011) Climate change cascades: shifts in oceanography, species' ranges and subtidal marine community dynamics in eastern Tasmania. J Exp Mar Biol Ecol 400:17-32

Jones CG, Lawton JH, Shachak M (1994) Organisms as ecosystem engineers. Oikos 69:373-386

* Kinlan BP, Graham MH, Sala E, Dayton PK (2003) Arrested development of giant kelp (Macrocystis pyrifera, Phaeophyceae) embryonic sporophytes: a mechanism for delayed recruitment in perennial kelps? J Phycol 39: 47-57

Kraemer GP, Chapman DJ (1991) Effects of tensile force and nutrient availability on carbon uptake and cell wall synthesis in blades of juvenile Egregia menziesii (Turn.) Aresch. (Phaeophyta). J Exp Mar Biol Ecol 149:267-277

Kyle DJ, Ohad I, Arntzen CJ (1984) Membrane protein damage and repair: selective loss of a quinone-protein function in chloroplast membranes. Proc Natl Acad Sci USA 81:4070-4074

* Maheswari M, Joshi DK, Saha R, Nagarajan S, Gambhir PN (1999) Transverse relaxation time of leaf water protons and membrane injury in wheat (Triticum aestivum L.) in response to high temperature. Ann Bot 84:741-745

Murata N, Takahashi S, Nishiyama Y, Allakhverdiev SI (2007) Photoinhibition of photosystem II under environmental stress. Biochim Biophys Acta Bioenerg 1767: 414-421

* Oliver ECJ, Wotherspoon SJ, Chamberlain MA, Holbrook NJ (2014) Projected Tasman Sea extremes in sea surface temperature through the twenty-first century. J Clim 27: 1980-1998

*Peckol P (1983) Seasonal physiological responses of two brown seaweed species from a North Carolina continental shelf habitat. J Exp Mar Biol Ecol 72:147-155

Platt T, Gallegos C, Harrison WG (1980) Photoinhibition of photosynthesis in natural assemblages of marine phytoplankton. J Mar Res 38:687-701

Poloczanska ES, Babcock RC, Butler A, Hobday AJ and others (2007) Climate change and Australian marine life. Oceanogr Mar Biol Annu Rev 45:407-478

Kalph PJ, Gademann R (2005) Rapid light curves: a powerful tool to assess photosynthetic activity. Aquat Bot 82: 222-237

Ramus J (1981) The capture and transduction of light energy. In: Lobban CS, Wynne MJ (eds) The biology of seaweeds. University of California Press, Los Angeles, CA, p 458-492

* Rauwolf U, Golczyk H, Greiner S, Herrmann RG (2010) Variable amounts of DNA related to the size of chloroplasts III. Biochemical determinations of DNA amounts per organelle. Mol Genet Genomics 283:35-47

* Reusch TBH (2014) Climate change in the oceans: evolutionary versus phenotypically plastic responses of marine animals and plants. Evol Appl 7:104-122

Ridgway KR (2007) Long-term trend and decadal variability of the southward penetration of the East Australian Current. Geophys Res Lett 34:1-5

Kochford DJ (1984) Nitrates in eastern Australian coastal waters. Aust J Mar Freshwater Res 35:385-397

Schiel DR, Foster MS (2015) The biology and ecology of giant kelp forests. University of California Press, Los Angeles, CA

Seely GR, Duncan MJ, Vidaver WE (1972) Preparative and analytical extraction of pigments from brown algae with dimethyl sulfoxide. Mar Biol 12:184-188 
Steneck RS, Graham MH, Bourque BJ, Corbett D, Erlandson JM, Estes JA, Tegner MJ (2002) Kelp forest ecosystems: biodiversity, stability, resilience and future. Environ Conserv 29:436-459

Stephens TA, Hepburn CD (2016) A kelp with integrity: Macrocystis pyrifera prioritises tissue maintenance in response to nitrogen fertilisation. Oecologia 182:71-84

Sun J, Sui X, Huang H, Wang S, Wei Y, Zhang Z (2014) Low light stress down-regulated Rubisco gene expression and photosynthetic capacity during cucumber (Cucumis sativus L.) leaf development. J Integr Agric 13:997-1007

Tait LW, Schiel DR (2013) Impacts of temperature on primary productivity and respiration in naturally structured macroalgal assemblages. PLOS ONE 8:e74413

Tatsumi M, Wright JT (2016) Understory algae and low light reduce recruitment of the habitat-forming kelp Ecklonia radiata. Mar Ecol Prog Ser 552:131-143

Editorial responsibility: Emily Carrington,

Friday Harbor, Washington, USA van den Hoek C (1982) The distribution of benthic marine algae in relation to the temperature regulation of their life histories. Biol J Linn Soc 18:81-144

* Wahl M, Jormalainen V, Eriksson BK, Coyer JA and others (2011) Stress ecology in Fucus: abiotic, biotic and genetic interactions. Adv Mar Biol 59:37-105

* Wernberg T, Thomsen MS, Tuya F, Kendrick GA, Staehr PA, Toohey BD (2010) Decreasing resilience of kelp beds along a latitudinal temperature gradient: potential implications for a warmer future. Ecol Lett 13:685-694

* Wheeler WN, Srivastava LM (1984) Seasonal nitrate physiology of Macrocystis integrifolia Bory. J Exp Mar Biol Ecol $76: 35-50$

Kiao X, de Bettignies T, Olsen YS, Agusti S, Duarte CM, Wernberg T (2015) Sensitivity and acclimation of three canopy-forming seaweeds to UVB radiation and warming. PLOS ONE 10:e0143031

Submitted: July 11, 2018; Accepted: February 14, 2019 Proofs received from author(s): March 12, 2019 